\title{
A Template for the Validation of DART-MS for Qualitative Seized Drugs Analysis
}

\author{
Edward Sisco $^{\mathrm{a}}$, Amber Burns $^{\mathrm{b}}$, Elizabeth Schneider ${ }^{\mathrm{b}}$, Laurel Bobka $^{\mathrm{b}}$, Ikenna Ikpeama ${ }^{\mathrm{b}}$ \\ ${ }^{a}$ National Institute of Standards and Technology, Gaithersburg, MD, USA \\ ${ }^{b}$ Maryland State Police Forensic Sciences Division, Pikesville, MD, USA
}

\begin{abstract}
Direct analysis in real time mass spectrometry (DART-MS) is an increasingly employed tool for a wide range of forensic applications including seized drug analysis. A significant body of research surrounds DART-MS for the analysis of seized drugs and how it can be used to address many of the challenges caused by the increased presence of emerging drugs and novel psychoactive substances. A lack of available resources to help address validation, operation, training, and data interpretation needs is just one of the hurdles that laboratories face when adopting new technologies, such as DART-MS. To provide additional resources to assist in validation development, this work provides a template that can be adopted or adapted for DART-MS or other ambient ionization mass spectrometry techniques for qualitative seized drug analysis. The template, which was created as a result of recent implementation efforts, provides a description of validation studies with a focus on understanding the potential challenges and limitations caused by the prevalence of novel psychoactive substances and other emerging drugs. The studies address accuracy and precision, reproducibility, specificity, sensitivity, environmental factors, use in casework, and robustness. In addition to providing a template for validation, the results obtained from completing these studies on two high-resolution DART-MS systems are also presented. This work, and the corresponding supplemental information, was created to add to the available resources that laboratories can leverage to assist in overcoming the adoption hurdles of ambient ionization mass spectrometry methods such as DARTMS.
\end{abstract}

Keywords: DART-MS; Validation; Seized Drug; Screening; Qualitative Analysis; Ambient Ionization 


\section{Introduction}

Forensic laboratories face a number of challenges with the introduction of new technologies including time, cost, and resource constraints. Even when cost is not a constraint, the need to develop a training plan, standard operating procedure, validation plan, and other documents can be overwhelming. When the technology is new to the laboratory it can add another layer of complexity as practitioners may be unfamiliar with the technique, its fundamentals, or even how to operate the system. To alleviate these obstacles, there is an increased need for resources that the community can leverage to lower the barriers for adoption.

One technology that laboratories are implementing with increasing frequency is direct analysis in real time mass spectrometry (DART-MS)[1-4]. DART-MS is one of the many ambient ionization mass spectrometry techniques that allow for rapid chemical analysis of samples with high sensitivity and minimal, if any, sample preparation. While DART-MS has been demonstrated for a wide range of forensic applications, qualitative seized drug analysis is the most widely researched and widely implemented[2]. DART-MS has been successfully demonstrated for the analysis of traditional drugs[5], novel psychoactive substances[6,7], steroids[8], pharmaceuticals[9], and other compounds of interest to a drug chemist[10]. Fortunately, the interest in this technology has led to a large base of scientific publications demonstrating various applications and data treatment approaches for the technique, but the prevalence of additional resources beyond that are few.

Some of the resources that do exist for laboratories that are considering implementing DART-MS or another ambient ionization mass spectrometry technique include the foundational validation work completed by Steiner et al. for the qualitative analysis of seized drugs[5] and for the confirmation of pharmaceutical samples using physical identifiers and DART-MS[9]. A freely-available spectral library also exists for seized drug analysis[11,12] as do a number of webinars and presentations that dive into fundamentals and real-world use of the technology[13,14]. Several textbooks also exist that can provide foundations for training practitioners who are new to the technique[15-18]. To supplement this body of existing resources, this work provides a template for the validation of DART-MS, or other ambient ionization mass spectrometry platforms, that laboratories can adapt for their own purposes. Given the change in the drug landscape since the foundational validation by Steiner et al, the validation described here emphasizes the need to ensure detection of novel psychoactive substances (NPSs) and other emerging drugs while also allowing for an understanding of the limitations of these techniques, specifically as it relates to isomer differentiation. Associated documentation to support implementation efforts has also been made available[19]. The results of this validation process from two instruments are also presented.

\section{Materials \& Methods}




\section{Instrument \& Method}

The two instruments used in this study were both JEOL AccuTOF 4G LC-Plus mass spectrometers (Peabody, MA, USA) coupled with DART-SVP ion sources (IonSense, Saugus, MA, USA). A suite of different software was used for data analysis and included msAxel (JEOL), MassMountaineer (Diablo Analytical, Antioch, CA, USA), and AnalyzerPro XD (SpectralWorks, Runcorn, Cheshire, UK). The NIST DART-MS Forensics Database was also used to assist in data analysis[11].

Both positive and negative ionization modes were investigated in all components of this validation except for non-probative casework (Study 6). All analyses used helium as the DART gas with a temperature of $400{ }^{\circ} \mathrm{C}$. For positive ionization mode a DART grid voltage of $+150 \mathrm{~V}$ was employed. Mass spectrometer settings included an $\mathrm{m} / \mathrm{z}$ scan range from $\mathrm{m} / \mathrm{z} 80$ to $\mathrm{m} / \mathrm{z} 800$ at $0.4 \mathrm{~s}$ per scan. An orifice 1 temperature of $120^{\circ} \mathrm{C}$, ring lens voltage of $+5 \mathrm{~V}$, orifice 2 voltage of $+5 \mathrm{~V}$ and ion guide voltage of $+800 \mathrm{~V}$ were used. Orifice 1 was cycled, using the parameter switching between $+20 \mathrm{~V},+30 \mathrm{~V},+60 \mathrm{~V}$, and $+90 \mathrm{~V}$ at $0.4 \mathrm{~s}$ per voltage. The negative mode method was identical to the positive mode, aside from the voltage polarity. Data acquisition was set to run for up to $180 \mathrm{~min}$ but was stopped whenever all samples for a particular study were collected. Polyethylene glycol (PEG-600) was sampled at the beginning and end of every run as well as approximately every $10 \mathrm{~min}$ throughout the run.

For the non-probative casework (Study 6) portion, only positive mode ionization was used, and the method was slightly modified. Instead of parameter switching for the orifice 1 voltage, a method with an orifice 1 voltage of $+30 \mathrm{~V}$ and another with $+60 \mathrm{~V}$ was used. In addition, instead of a 180 min acquisition time the method was shortened to $1 \mathrm{~min}$ and data was collected using the Sequence Table instead of the Single Run option, which was used for all other studies. A single non-probative case sample was analyzed in a single 1 min run along with a tetracaine verification. A $+30 \mathrm{~V}$ orifice 1 datafile was collected for each sample and a $+60 \mathrm{~V}$ datafile was collected when additional fragmentation was needed to assist in compound identification. This study also incorporated the use of tetracaine as an internal standard, which has been previously discussed elsewhere[20].

\section{Data Processing}

The $\mathrm{m} / \mathrm{z}$ (mass) calibration was completed using PEG-600 which was sampled, at a minimum, at the beginning and end of each collected datafile for all studies except non-probative casework (Study 6). A full calibration was completed approximately weekly in msAxel using a PEG-600 spectrum. For each datafile, a mass drift compensation was also applied using the multi-point $\mathrm{m} / \mathrm{z}$ drift compensation function within msAxel along with an $\mathrm{m} / \mathrm{z}$ value corresponding to one of the major peaks in the PEG-600 spectrum 
(typically $\mathrm{m} / \mathrm{z} 415.2538$ in positive ionization mode and $\mathrm{m} / \mathrm{z} 295.1393$ in negative ionization mode). For the non-probative casework study (Study 6), tetracaine $(\mathrm{m} / \mathrm{z}$ 265.1916) was used as the mass drift compensation ion.

For studies where the accuracy of the $\mathrm{m} / \mathrm{z}$ calibration was investigated, the mass spectra of interest were extracted in msAxel, saved as ".txt" files and searched against an in-house search list[19] in MassMoutaineer using the "Search From List" functionality. Constraints of $\pm 5 \mathrm{mmu}( \pm 0.005 \mathrm{Da})$ for the mass tolerance and a minimum relative intensity threshold of $5 \%$ were used. For studies where peak area was measured, extracted ion chronograms (EICs) corresponding to the base peak for the compound of interest were extracted and integrated using the msAxel default integration settings.

For studies where comparison to a spectral library was required, raw datafiles were converted to ".netCDF" datafiles in msAxel and then opened in AnalyzerPro XD. The mass spectra were extracted using the peak detection functionality in AnalyzerPro and then searched against the NIST DART-MS Forensics Database (for positive ionization mode) or an in-house created library (for negative ionization mode). While this was completed using AnalyzerPro, it can also be done by extracting the spectra in msAxel and then using the "NIST Search" functionality in MassMountaineer.

\section{Chemicals \& Consumables}

Both single- and multi-component standard solutions were used in this work. Individual standards were purchased from Cayman Chemical (Ann Arbor, MI, USA) as either powders or $1 \mathrm{mg} / \mathrm{mL}$ methanolic solutions. For analyses that required a single-component solution, $50 \mu \mathrm{g} / \mathrm{mL}$ solutions were created by either dissolving powder in methanol or diluting $1 \mathrm{mg} / \mathrm{mL}$ stock solutions in methanol. For sensitivity measurements, solutions were diluted, gravimetrically, in methanol to concentrations as low as $0.5 \mu \mathrm{g} / \mathrm{mL}$. Two multi-component solutions were used in this validation to study accuracy, precision, reproducibility, robustness, and environmental effects. A 15-component solution, comprised of the compounds listed in Table 1, was used for positive mode analysis. A three-component solution, comprised of the compounds listed in Table 2, was used for negative mode analysis. Solutions were prepared so that the concentration of all compounds in the mixture was approximately $50 \mu \mathrm{g} / \mathrm{mL}$.

Polyethylene glycol 600 (PEG-600) (Sigma-Aldrich, St. Louis, MO, USA) was used as the mass spectrometer tuning compound and tetracaine (Sigma-Aldrich) was used as an internal standard. All sampling was completed using glass microcapillaries (Corning, Corning, NY, USA). 
Table 1. Compounds present in the 15-component solution that was used for the accuracy and precision, reproducibility, environmental, and robustness components of the validation study in positive ionization mode. The monoisotopic molecular masses are listed. All compounds readily formed a protonated molecule, $[\mathrm{M}+\mathrm{H}]^{+}$, listed as the DART-MS base peak.

\begin{tabular}{|c|c|c|c|}
\hline Compound & Formula & $\begin{array}{c}\text { Molecular } \\
\text { Mass (Da) }\end{array}$ & $\begin{array}{c}\text { DART-MS Base } \\
\text { Peak }(\boldsymbol{m} / \boldsymbol{z})\end{array}$ \\
\hline Methamphetamine & $\mathrm{C}_{10} \mathrm{H}_{15} \mathrm{~N}$ & 149.120 & 150.128 \\
\hline$\alpha$-Pyrrolidinobutiophenone & $\mathrm{C}_{14} \mathrm{H}_{19} \mathrm{NO}$ & 217.147 & 218.154 \\
\hline Butylone & $\mathrm{C}_{12} \mathrm{H}_{15} \mathrm{NO}_{3}$ & 221.105 & 222.113 \\
\hline Ethylone & $\mathrm{C}_{12} \mathrm{H}_{15} \mathrm{NO}_{3}$ & 221.105 & 222.113 \\
\hline$\alpha$-Pyrrolidinovalerophenone & $\mathrm{C}_{15} \mathrm{H}_{21} \mathrm{NO}$ & 231.162 & 232.170 \\
\hline Phencyclidine & $\mathrm{C}_{17} \mathrm{H}_{25} \mathrm{~N}$ & 243.199 & 244.207 \\
\hline Tenocyclidine & $\mathrm{C}_{15} \mathrm{H}_{23} \mathrm{NS}$ & 249.155 & 250.163 \\
\hline Cocaine & $\mathrm{C}_{17} \mathrm{H}_{21} \mathrm{NO}_{4}$ & 303.147 & 304.155 \\
\hline Alprazolam & $\mathrm{C}_{17} \mathrm{H}_{13} \mathrm{ClN}_{4}$ & 308.083 & 309.091 \\
\hline Stanozolol & $\mathrm{C}_{21} \mathrm{H}_{32} \mathrm{~N}_{2} \mathrm{O}$ & 328.251 & 329.259 \\
\hline Heroin & $\mathrm{C}_{21} \mathrm{H}_{23} \mathrm{NO}_{5}$ & 369.158 & 370.165 \\
\hline Furanyl Fentanyl & $\mathrm{C}_{24} \mathrm{H}_{26} \mathrm{~N}_{2} \mathrm{O}_{2}$ & 374.199 & 375.207 \\
\hline Furanyl Fentanyl 3-Furancarboxamide & $\mathrm{C}_{24} \mathrm{H}_{26} \mathrm{~N}_{2} \mathrm{O}_{2}$ & 374.199 & 375.207 \\
\hline 5-Fluoro ADB & $\mathrm{C}_{20} \mathrm{H}_{28} \mathrm{FN}_{3} \mathrm{O}_{3}$ & 377.211 & 378.219 \\
\hline Nandrolone Decanoate & $\mathrm{C}_{28} \mathrm{H}_{44} \mathrm{O}_{3}$ & 428.328 & 429.336 \\
\hline
\end{tabular}

Table 2. Compounds present in the three-component solution that was used for the accuracy and precision, reproducibility, environmental, and robustness components of the validation study in negative ionization mode. The monoisotopic molecular masses are listed. All compounds readily formed a deprotonated molecule, $[\mathrm{M}-\mathrm{H}]^{-}$, listed as the DART-MS base peak.

\begin{tabular}{|c|c|c|c|}
\hline Compound & Formula & $\begin{array}{c}\text { Molecular } \\
\text { Mass (Da) }\end{array}$ & $\begin{array}{c}\text { DART-MS Base } \\
\text { Peak }(\boldsymbol{m} / \boldsymbol{z})\end{array}$ \\
\hline Gamma Hydroxy-Butyrate $(\mathrm{GHB})$ & $\mathrm{C}_{4} \mathrm{H}_{8} \mathrm{O}_{3}$ & 104.047 & 103.039 \\
\hline Secobarbital & $\mathrm{C}_{12} \mathrm{H}_{18} \mathrm{~N}_{2} \mathrm{O}_{3}$ & 238.132 & 237.124 \\
\hline AB-FUBINACA & $\mathrm{C}_{20} \mathrm{H}_{21} \mathrm{FN}_{4} \mathrm{O}_{2}$ & 368.165 & 367.157 \\
\hline
\end{tabular}

\section{Overview of the Validation Process}

\section{Study 1. Accuracy and Precision}

To measure accuracy, the 15-component solution (positive mode, Table 1) and three-component solution (negative mode, Table 2) were analyzed ten times over the span of one day to evaluate the accuracy of the $\mathrm{m} / \mathrm{z}$ calibration. The $\mathrm{m} / \mathrm{z}$ assignments for the base peaks in the low orifice 1 voltage $( \pm 20 \mathrm{~V})$ spectra were evaluated to determine if they consistently fell within a \pm 0.005 Da tolerance of the calculated theoretical masses. To process this data, spectra were extracted in msAxel and processed in MassMountaineer using the Search From List functionality.

In addition to evaluating mass tolerance of the base peaks, the ability to consistently produce accurate fragment peaks was also evaluated. Single-component solutions of each of the components (Table 1 and Table 2) were run ten times over the span of one day. The base peak or secondary base peak produced in the higher orifice 1 voltage ( $\pm 30 \mathrm{~V}, \pm 60 \mathrm{~V}$, and $\pm 90 \mathrm{~V}$ ) spectra for each compound was then compared to 
ensure the instrument produced repeatable fragment ions and accurately calibrated ions for each compound. Data was processed in the same manner as above.

\section{Study 2. Reproducibility}

To measure reproducibility, the 15-component solution (positive mode, Table 1) and three-component solution (negative mode, Table 2) were analyzed five times per a set on seven separate days over a threeweek period to evaluate the reproducibility of the system. The $m / z$ assignments for the base peaks in the low orifice 1 voltage $( \pm 20 \mathrm{~V})$ spectra were monitored to determine if they consistently fell within a \pm 0.005 Da tolerance of the calculated theoretical mass for all compounds. In addition to measuring the reproducibility of the $\mathrm{m} / \mathrm{z}$ values, the ability to reproducibly calibrate and mass drift compensate the mass spectrometer using PEG-600 was also examined. To monitor calibration, the "1-R" value obtained during the calibration process in msAxel was noted and was considered passing if it was less than $9.9 \times 10^{-12}$ with the removal of up to one peak at the beginning or end of the calibration range. Mass drift compensation was considered passing if the process was successfully completed. Finally, a methanol blank was analyzed inbetween samplings of the multi-component solutions to monitor the potential for carryover or false positive identification of peaks in a blank spectrum. This was completed by extracting and searching the methanol spectra in the same manner as the solution spectra.

\section{Study 3. Specificity}

Specificity of the system was evaluated through two separate studies for each ionization mode. In the first study, single-component solutions for all compounds listed in Table 1 and Table 2 were analyzed five times each and the resulting mass spectra from each of the four fragmentation voltages were searched against the NIST DART Forensics library[11,12] using NIST MS Search[21] to identify how well spectra from different compounds could be differentiated. An in-house library was created due to the lack of a publicly available negative ionization mode library. The resulting reverse match factor (obtained using NIST MS Search) was noted as were instances where the compound analyzed was not returned as the top match.

Given that isomer differentiation is a known limitation of DART-MS analysis, a second study was completed to understand the limitations of the system in differentiating commonly seen isomer sets. Singlecomponent solutions of the compounds listed in Table 3 were analyzed across the four orifice 1 voltages and searched against the NIST DART Forensics library in the same manner as above.

Table 3. Compounds used for the isomer specificity study (Study 3) which focused on understanding the ability to differentiate commonly seen isomers. 


\begin{tabular}{|c|c|c|}
\hline \multicolumn{3}{|c|}{ Positive Mode Sets } \\
\hline Set 1 & Set 3 & Set 5 \\
\hline Methamphetamine & Cyclopropyl Fentanyl & 6-APDB \\
\hline \multirow[t]{3}{*}{ Phentermine } & Crotonyl Fentanyl & 5-APDB \\
\hline & Methacryl Fentanyl & Buphedrone \\
\hline & & Dimethylcathinone \\
\hline Set 2 & Set 4 & Ethcathinone \\
\hline Butylone & $\mathrm{m}-\mathrm{FBF}$ & Mephedrone \\
\hline Dimethylone & o-FBF & 2-MMC \\
\hline Ethylone & p-FBF & MMAI \\
\hline 3,4-EDMC & $\mathrm{m}$-FiBF & \\
\hline \multirow[t]{2}{*}{ 3,4-MDPA } & o-FiBF & \\
\hline & p-FiBF & \\
\hline \multicolumn{3}{|c|}{ Negative Mode Set } \\
\hline AB-FUBINACA & $\begin{array}{l}\text { AB-FUBINACA 2'- } \\
\text { indazole isomer }\end{array}$ & $\begin{array}{l}\text { AB-FUBINACA 2- } \\
\text { fluorobenzyl isomer }\end{array}$ \\
\hline AB-7-FUBAICA & $\begin{array}{l}\text { AB-FUBINACA } \\
\text { isomer } 1\end{array}$ & \\
\hline
\end{tabular}

\section{Study 4. Sensitivity}

Sensitivity was evaluated in accordance with ASTM Method E2677[22], which provided a statistically calculated limit of detection (LOD) with an assigned confidence interval. The sensitivity was measured for each compound in Table 1 and Table 2, individually. Solutions of known concentration were created, gravimetrically, from solid standards or stock solutions. Nominal solution concentrations of $0.5 \mu \mathrm{g} \mathrm{mL}{ }^{-1}, 1$ $\mu \mathrm{g} \mathrm{mL}{ }^{-1}, 5 \mu \mathrm{g} \mathrm{mL}^{-1}, 10 \mu \mathrm{g} \mathrm{mL}^{-1}$, and $25 \mu \mathrm{g} \mathrm{mL}^{-1}$, along with pure methanol $\left(0 \mu \mathrm{g} \mathrm{mL}^{-1}\right)$ were used. A template for the creation of the gravimetric solutions is provided elsewhere[19]. For each compound, ten replicates of each solution concentration were analyzed by pipetting $1 \mu \mathrm{L}$ aliquots directly onto the glass microcapillary. Once analyzed, integrated peak areas from the extracted ion chronograms (EICs) of the base peak for each compound were obtained. Calculation of the LOD was completed by entering the concentrations and peak areas into the ASTM E2677 LOD calculator[23] using a confidence limit of 0.10 (90\% confidence).

\section{Study 5. Environmental (Solvent) Effects}

The effects of solvent on instrument response were investigated by creating the 15-component (positive mode) and three-component (negative mode) solutions at the same concentration $(50 \mu \mathrm{g} / \mathrm{mL})$ used in the accuracy and precision studies in three additional solvents (acetone, chloroform and hexane). These solutions, along with the methanolic solution, were analyzed, in triplicate. Once analyzed, the $\pm 20 \mathrm{~V}$ orifice 1 voltage mass spectra were extracted and searched using MassMountaineer to determine if solvent would 
have an effect on compound detection or compound identification. In addition, the integrated peak areas from the EICs of the base peaks for each compound were extracted and plotted to understand the effect of solvent on the response (intensity) for each compound.

\section{Study 6. Non-Probative Casework}

In order to establish the use of this technique in a real-world implementation, a blind sampling study was completed. A total of 50 adjudicated or mock case samples were analyzed with the DART-MS. For this study, the use of a tetracaine internal standard was incorporated into the case extract, but analysis could be done without an internal standard. Samples were prepared by dissolving $1 \mathrm{mg}$ to $2 \mathrm{mg}$ of powder into $1 \mathrm{~mL}$ of methanol containing tetracaine at $0.1 \mathrm{mg} / \mathrm{mL}$. A more in-depth explanation of this approach, and the work involved in developing and evaluating tetracaine as an internal standard compound can be found elsewhere[20]. Analysis was completed using a sequence-based run approach with 1 min analyses. In the 1 min run, the tetracaine internal standard was first analyzed, followed by three analyses of the sample. The resulting mass spectra were extracted and analyzed in the same manner as the specificity study and compared to the GC-MS results. A successful identification was defined as a positive search result (greater than $5 \%$ relative abundance and within $\pm 5 \mathrm{mmu}$ of the theoretical mass) of all detectable controlled substances found in the GC-MS analysis along with identification of the internal standard in the DARTMS mass spectra.

\section{Study 7. Method Robustness}

To establish robustness of the technology, a second practitioner completed the reproducibility study (Study 2) using the same solutions from Study 2. This allowed for investigation of any analyst-dependent parameters.

A template for compiling the data for each of the above listed studies is provided elsewhere[19].

\section{Results \& Discussion}

\section{Study 1. Accuracy and Precision}

Results for the accuracy and precision studies for both instruments and both ionization modes produced peaks with $m / z$ values that were within the \pm 0.005 Da tolerance for all compounds. Figure 1 shows the drift (difference between measured and theoretical $\mathrm{m} / \mathrm{z}$ values), in Da, from the theoretical monoisotopic mass for all compounds in the 15-component solution analyzed in positive mode. Supplemental Figure 1 shows the results for all compounds in the three-component solution in negative mode. 

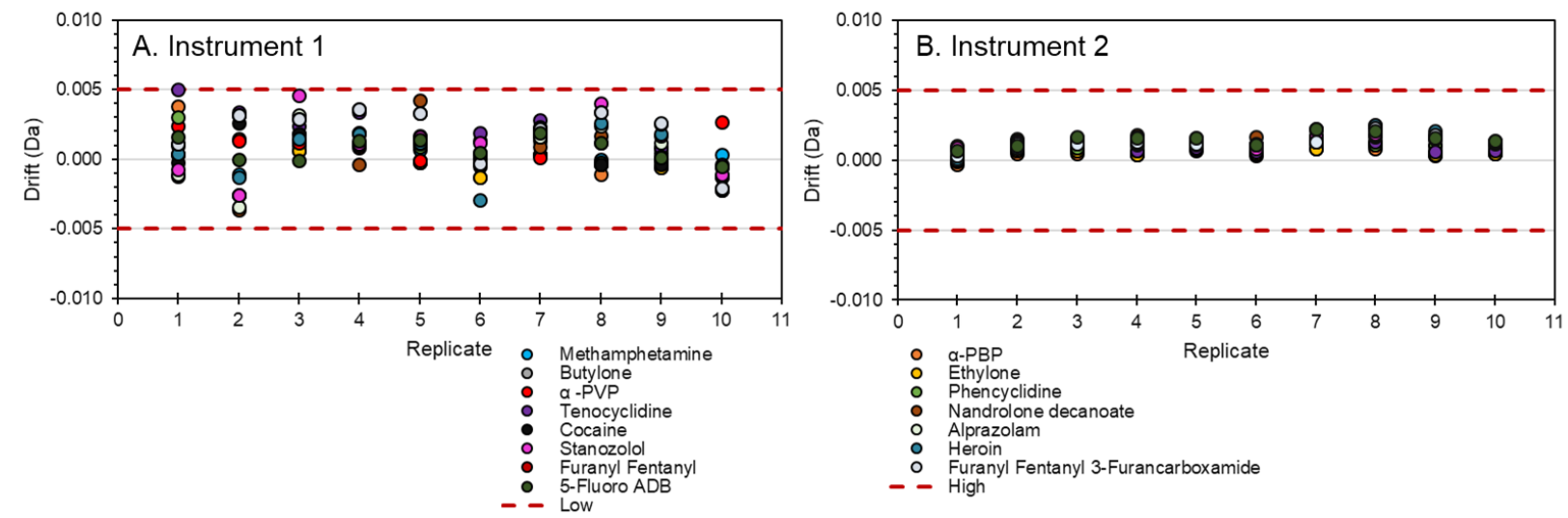

Figure 1. Calculated $\mathrm{m} / \mathrm{z}$ drifts from theoretical values for the ten replicate analyses for the positive mode accuracy and precision study (Study 1) for Instrument 1 (A., left) and Instrument 2 (B., right). The theoretical $\mathrm{m} / \mathrm{z}$ values corresponding to this data can be found in (Table 1). The red dotted lines indicate the high and low bounds of the allowable drift.

Analysis of the higher orifice 1 fragmentation voltage spectra for both positive and negative ionization modes produced $\mathrm{m} / \mathrm{z}$ values that were consistently within the $\pm 0.005 \mathrm{Da}$ drift window for all compounds at all orifice 1 voltages examined. Supplemental Figures 2, 3, and 4 show the drift for the major peaks observed in the $+30 \mathrm{~V},+60 \mathrm{~V}$, and $+90 \mathrm{~V}$ orifice 1 voltages for all 15 compounds analyzed individually in positive mode. Supplemental Figures 5, 6, and 7 show the same data obtained from the $-30 \mathrm{~V},-60 \mathrm{~V}$, and $90 \mathrm{~V}$ orifice 1 voltages for all 3 compounds analyzed individually in negative mode. Supplemental Tables 1 and 2 show the theoretical $\mathrm{m} / \mathrm{z}$ values used to generate the data for comparison for the $\pm 30 \mathrm{~V}, \pm 60 \mathrm{~V}$, and $\pm 90 \mathrm{~V}$ spectra.

\section{Study 2. Reproducibility}

As a result of the reproducibility studies, the $m / z$ values corresponding to all compounds were found to be within the \pm 0.005 Da tolerance specified for all replicates from all seven days of analysis. The standard deviations from the theoretical $\mathrm{m} / \mathrm{z}$ values ranged from \pm 0.0005 Da to $\pm 0.0012 \mathrm{Da}$. The coefficient of variation was found to be at or below $0.006 \%$ for all compounds. Table 4 shows the summary results for the positive and negative reproducibility studies for Instrument 1 . Supplemental Table 3 shows the summary results for Instrument 2. Supplemental Figure 8 shows the calculated drift from the theoretical monoisotopic mass for all compounds in the 15-componentsolution in positive mode across the seven days while Supplemental Figure 9 shows the results for the three-component solution in negative mode. 
Table 4. Summary results for the reproducibility studies for Instrument 1.

\begin{tabular}{|c|c|c|c|c|c|c|}
\hline & $\begin{array}{c}\text { Theoretical } \\
\mathrm{m} / \mathrm{z}\end{array}$ & $\begin{array}{c}\text { Minimum } \\
\mathrm{m} / \mathrm{z}\end{array}$ & $\begin{array}{c}\text { Maximum } \\
\mathrm{m} / \mathrm{z}\end{array}$ & $\begin{array}{c}\text { Average } \\
\mathrm{m} / \mathrm{z}\end{array}$ & $\begin{array}{l}\text { Standard } \\
\text { Deviation }\end{array}$ & $\begin{array}{l}\text { Coefficient of } \\
\text { Variation (\%) }\end{array}$ \\
\hline \multicolumn{7}{|c|}{ Positive Ionization Mode } \\
\hline Methamphetamine & 150.1277 & 150.1258 & 150.1289 & 150.1277 & 0.0008 & 0.0006 \\
\hline$\alpha$-PBP & 218.1539 & 218.1520 & 218.1551 & 218.1537 & 0.0008 & 0.0004 \\
\hline Butylone & 222.1124 & 222.1107 & 222.1135 & 222.1122 & 0.0008 & 0.0004 \\
\hline Ethylone & 222.1124 & 222.1107 & 222.1135 & 222.1122 & 0.0008 & 0.0004 \\
\hline$\alpha-\mathrm{PVP}$ & 232.1695 & 232.1681 & 232.1707 & 232.1694 & 0.0007 & 0.0003 \\
\hline Phencyclidine & 244.2059 & 244.2047 & 244.2077 & 244.2062 & 0.0008 & 0.0003 \\
\hline Tenocyclidine & 250.1624 & 250.1602 & 250.1648 & 250.1630 & 0.0012 & 0.0005 \\
\hline Nandrolone decanoate & 429.3363 & 429.3342 & 429.3395 & 429.3370 & 0.0011 & 0.0003 \\
\hline Cocaine & 304.1543 & 304.1533 & 304.1569 & 304.1547 & 0.0008 & 0.0003 \\
\hline Alprazolam & 309.0901 & 309.0892 & 309.0927 & 309.0908 & 0.0009 & 0.0003 \\
\hline Stanozolol & 329.2587 & 329.2580 & 329.2623 & 329.2598 & 0.0010 & 0.0003 \\
\hline Heroin & 370.1649 & 370.1629 & 370.1678 & 370.1652 & 0.0011 & 0.0003 \\
\hline Furanyl Fentanyl & 375.2067 & 375.2055 & 375.2107 & 375.2075 & 0.0012 & 0.0003 \\
\hline $\begin{array}{l}\text { Furanyl Fentanyl 3- } \\
\text { Furancarboxamide }\end{array}$ & 375.2067 & 375.2055 & 375.2107 & 375.2075 & 0.0012 & 0.0003 \\
\hline 5-Fluoro ADB & 378.2187 & 378.2164 & 378.2219 & 378.2193 & 0.0011 & 0.0003 \\
\hline \multicolumn{7}{|c|}{ Negative Ionization Mode } \\
\hline AB-FUBINACA & 103.0390 & 103.0388 & 103.0406 & 103.0395 & 0.0005 & 0.0005 \\
\hline GHB & 237.1234 & 237.1217 & 237.1247 & 237.1236 & 0.0006 & 0.0003 \\
\hline Secobarbital & 367.1565 & 367.1536 & 367.1582 & 367.1565 & 0.0010 & 0.0003 \\
\hline
\end{tabular}

PEG calibration residuals were found to fall below $10^{-12}$ for all runs in the reproducibility study for both positive and negative modes. Residual values for the PEG calibrant ranged from $6.3 \times 10^{-13}$ to $1.6 \times 10^{-12}$ for positive mode and $1.7 \times 10^{-13}$ to $1.8 \times 10^{-12}$ for negative mode. The multi-point $\mathrm{m} / \mathrm{z}$ drift compensation function was also employed, in lieu of calibration, for some of the datafiles and was found to work as well as traditional single point calibration.

Analysis of the methanol blanks from the positive mode runs on multiple days on both instruments produced instances where a peak with a similar $m / z$ value to cocaine was found. Given that there are no intense peaks in the methanol spectra, the $5 \%$ threshold used for searching was lower than the intensity of background noise peaks. The peaks that were identified as cocaine were found to be at a similar level to the background noise, and therefore not related to carryover. In negative mode, no peaks were detected in the methanol blanks that corresponded to $\mathrm{m} / \mathrm{z}$ values of interest.

\section{Study 3. Specificity}


The results of the first specificity study for Instrument 1 are presented in Table 5 (Instrument 2 data is shown in Supplemental Table 4). As expected, isomer differentiation (i.e. butylone and ethylone or furanyl fentanyl and furanyl fentanyl 3-furancarboxamide) was not always possible, especially at low ( $\pm 20 \mathrm{~V}$ and $\pm 30 \mathrm{~V}$ ) orifice 1 voltages. This is a known limitation of DART-MS analysis that utilizes a time-of-flight mass spectrometer[2]. Six of the 15 compounds in positive mode had at least one other isomer or related compound returned as a higher hit in MS Search which, again, is expected given the spectral similarity of compounds with identical molecular masses of fragmentation. There were no instances where the compound of interest was not identified in the top five hits. MS Search scores were above 720 a.u. for all compounds across all voltages (at or above 698 a.u. for Instrument 2), indicating good agreement with library spectra. Results across the two instruments were comparable, though Instrument 2 did have fewer instances where the top hit returned was not the compound of interest. In negative ionization mode (Supplemental Tables 5), significantly higher search scores (compared to positive mode) were observed for both instruments and may be an artifact of the mass spectral library being created in-house.

Table 5. Average reverse search scores and lists of other compounds that produced reverse search scores higher than the compound of interest for the positive mode study on Instrument 1 . The number in parentheses next to the compounds indicates how many times, out of the five replicate spectra, that the compound returned a reverse search score greater than the compound of interest.

\begin{tabular}{|c|c|c|c|c|c|c|c|c|}
\hline 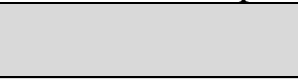 & \multicolumn{4}{|c|}{$\begin{array}{c}\text { Average Reverse Search } \\
\text { Score }\end{array}$} & \multicolumn{4}{|c|}{ Other Compounds That Produced Scores Higher Than Compound } \\
\hline & $20 \mathrm{~V}$ & $30 \mathrm{~V}$ & $60 \mathrm{~V}$ & $90 \mathrm{~V}$ & $20 \mathrm{~V}$ & $30 \mathrm{~V}$ & $60 \mathrm{~V}$ & $90 \mathrm{~V}$ \\
\hline Methamphetamine & 809 & 827 & 821 & 848 & Phentermine (1) & Phentermine (1) & Amphetamine (3) & $\begin{array}{c}\text { Amphetamine (3) } \\
\text { Benzphetamine (1) } \\
\text { n-Ethylamphetamine (2) }\end{array}$ \\
\hline$\alpha-\mathrm{PBP}$ & 874 & 887 & 865 & 918 & MePPP (2) & None & None & None \\
\hline Butylone & 840 & 787 & 870 & 865 & $\begin{array}{c}\text { Ethylone (5) } \\
\text { Metaxalone (3) }\end{array}$ & $\begin{array}{c}\text { Ethylone (4) } \\
\text { Metaxalone (1) }\end{array}$ & None & None \\
\hline Ethylone & 863 & 906 & 890 & 859 & $\begin{array}{c}\text { Butylone (1) } \\
\text { Metaxalone (1) }\end{array}$ & None & None & Butylone (1) \\
\hline$\alpha-\mathrm{PVP}$ & 838 & 771 & 813 & 846 & None & None & None & None \\
\hline Phencyclidine & 838 & 810 & 862 & 851 & None & None & None & None \\
\hline Tenocyclidine & 938 & 915 & 979 & 793 & None & None & None & None \\
\hline Nandrolone decanoate & 752 & 720 & 760 & 760 & None & None & None & None \\
\hline Cocaine & 767 & 839 & 875 & 890 & None & None & None & None \\
\hline Alprazolam & 928 & 927 & 920 & 928 & None & None & None & None \\
\hline Stanozolol & 922 & 914 & 905 & 890 & None & None & None & None \\
\hline Heroin & 772 & 763 & 767 & 868 & None & None & None & None \\
\hline Furanyl Fentanyl & 817 & 838 & 830 & 871 & 3-Furanyl Fent (3) & 3-Furanyl Fent (2) & 3-Furanyl Fent (3) & 3-Furanyl Fent (3) \\
\hline $\begin{array}{l}\text { Furanyl Fentanyl 3- } \\
\text { Furancarboxamide }\end{array}$ & 847 & 855 & 793 & 837 & $\begin{array}{l}\text { 2-Furanyl Fentanyl } \\
\text { (1) }\end{array}$ & None & $\begin{array}{l}\text { 2-Furanyl Fentanyl } \\
\text { (1) }\end{array}$ & 2-Furanyl Fentanyl (1) \\
\hline 5-Fluoro ADB & 968 & 975 & 958 & 860 & None & None & None & None \\
\hline
\end{tabular}

Abbreviation: "3-Furanyl Fent" is Furanyl Fentanyl 3-Furancarboximide. 
As expected in the second specificity study, isomer differentiation was also not always possible, especially at low ( $\pm 20 \mathrm{~V}$ and $\pm 30 \mathrm{~V}$ ) orifice 1 voltages. Table 6 shows the results of the second specificity study on Instrument 1 (Supplemental Table 6 shows the results for Instrument 2). For isomer set 1, differentiation of methamphetamine and phentermine was not possible at low fragmentation voltages but was possible at high fragmentation voltages, though methamphetamine and other amphetamines produce similar spectra at high fragmentation voltages. For isomer Set 2 and isomer Set 5, the synthetic cathinones, differentiation was not possible at low fragmentation voltages, as expected, as the spectra were dominated by the protonated molecule. Higher orifice 1 voltage spectra, however, did allow for a greater degree of differentiation than expected. This trend was also observed for the synthetic cannabinoid set in negative mode (Supplemental Table 7). For the fentanyl isomer sets, Set 3 and Set 4, differentiation across the fragmentation voltages was not possible due to both identical protonated molecules and similar fragmentation spectra within each set. The results of these studies highlight that leveraging the higher fragmentation voltages may assist in isomer differentiation for some cases. While this is true for pure compounds, the added benefit of the higher fragmentation spectra may not be realized for multi-component solutions unless advanced search algorithms are employed.

Table 6. Average reverse search scores and lists of other compounds that produced reverse search scores higher than the compound of interest for the positive mode study in Instrument 1 . The number in parentheses next to the compounds indicates how many times, out of the five replicate spectra, that compound returned a reverse search score greater than the compound of interest.

\begin{tabular}{|c|c|c|c|c|c|c|c|c|}
\hline & \multicolumn{4}{|c|}{$\begin{array}{l}\text { Average Reverse Search } \\
\text { Score }\end{array}$} & \multicolumn{4}{|c|}{ Other Compounds That Produced Scores Higher Than Compound } \\
\hline & $20 \mathrm{~V}$ & $30 \mathrm{~V}$ & $60 \mathrm{~V}$ & $90 \mathrm{~V}$ & $20 \mathrm{~V}$ & $30 \mathrm{~V}$ & $60 \mathrm{~V}$ & $90 \mathrm{~V}$ \\
\hline \multicolumn{9}{|c|}{ Set 1} \\
\hline Methamphetamine & 809 & 827 & 821 & 848 & Phentermine (1) & Phentermine (1) & Amphetamine (3) & $\begin{array}{c}\text { Amphetamine (3) } \\
\text { Benzphetamine (1) } \\
\text { n-Ethylamphetamine (2) }\end{array}$ \\
\hline Phentermine & 848 & 795 & 880 & 857 & None & None & None & None \\
\hline \multicolumn{9}{|c|}{ Set 2} \\
\hline Butylone & 840 & 787 & 870 & 865 & $\begin{array}{c}\text { Ethylone (5) } \\
\text { Metaxalone (3) }\end{array}$ & $\begin{array}{c}\text { Ethylone (4) } \\
\text { Metaxalone (1) }\end{array}$ & None & None \\
\hline Dimethylone & 939 & 942 & 966 & 986 & $\begin{array}{l}\text { EDMC (1) } \\
\text { MDPA (4) } \\
\end{array}$ & MDPA (2) & None & None \\
\hline Ethylone & 863 & 906 & 890 & 859 & $\begin{array}{c}\text { Butylone (1) } \\
\text { Metaxalone (1) }\end{array}$ & None & None & Butylone (1) \\
\hline 3,4-EDMC & 920 & 915 & 758 & 981 & $\begin{array}{l}\text { Dimethylone (2) } \\
\text { MDPA (2) }\end{array}$ & None & None & None \\
\hline 3,4-MDPA & 971 & 958 & 944 & 989 & None & None & None & None \\
\hline \multicolumn{9}{|c|}{ Set 3} \\
\hline Cyclopropyl Fent. & 791 & 821 & 863 & 880 & $\begin{array}{l}\text { Crotonyl (3) } \\
\text { Methacryl (3) }\end{array}$ & $\begin{array}{l}\text { Crotonyl (4) } \\
\text { Methacryl (4) }\end{array}$ & $\begin{array}{l}\text { Crotonyl (1) } \\
\text { Methacryl (1) }\end{array}$ & None \\
\hline Crotonyl Fent. & 833 & 859 & 837 & 775 & Methacryl (4) & Methacryl (5) & $\begin{array}{l}\text { Cyclopropyl (4) } \\
\text { Methacryl (1) }\end{array}$ & $\begin{array}{l}\text { Cyclopropyl (5) } \\
\text { Methacryl (5) }\end{array}$ \\
\hline
\end{tabular}




\begin{tabular}{|c|c|c|c|c|c|c|c|c|}
\hline Methacryl Fent. & 804 & 858 & 837 & 836 & None & $\begin{array}{c}\text { Crotonyl (3) } \\
\text { Cyclopropyl (2) }\end{array}$ & $\begin{array}{c}\text { Crotonyl (2) } \\
\text { Cyclopropyl (3) }\end{array}$ & Cyclopropyl (5) \\
\hline \multicolumn{9}{|c|}{ Set 4} \\
\hline $\mathrm{m}-\mathrm{FBF}$ & 787 & 859 & 851 & 872 & $\begin{array}{l}\text { o-FBF (3) } \\
\text { p-FBF (3) } \\
\text { p-FiBF (5) }\end{array}$ & $\begin{array}{l}\text { o-FBF (1) } \\
\text { p-FBF (5) } \\
\text { p-FiBF (1) }\end{array}$ & $\begin{array}{l}\text { m-FiBF (1) } \\
\text { o-FiBF (5) } \\
\text { p-FBF (5) } \\
\text { p-FiBF (4) }\end{array}$ & $\begin{array}{l}\text { m-FiBF (2) } \\
\text { o-FiBF (4) } \\
\text { p-FBF (3) } \\
\text { p-FiBF (5) }\end{array}$ \\
\hline o-FBF & 805 & 859 & 873 & 869 & $\begin{array}{l}\text { o-FiBF (2) } \\
\text { p-FiBF (5) }\end{array}$ & $\begin{array}{l}\text { m-FBF (4) } \\
\text { p-FBF (5) } \\
\text { p-FiBF (3) }\end{array}$ & p-FBF (4) & $\begin{array}{l}\text { m-FBF (1) } \\
\text { m-FiBF (5) } \\
\text { p-FBF (1) } \\
\text { p-FiBF(5) }\end{array}$ \\
\hline $\mathrm{p}-\mathrm{FBF}$ & 771 & 910 & 891 & 947 & $\begin{array}{l}\text { o-FiBF (2) } \\
\text { p-FiBF (5) }\end{array}$ & None & None & None \\
\hline $\mathrm{m}-\mathrm{FiBF}$ & 822 & 850 & 822 & 904 & $\begin{array}{l}\text { m-FBF (4) } \\
\text { p-FBF (4) } \\
\text { p-FiBF (5) }\end{array}$ & $\begin{array}{l}\text { m-FBF (4) } \\
\text { o-FBF (2) } \\
\text { o-FiBF (1) } \\
\text { p-FBF (4) } \\
\text { p-FiBF (5) }\end{array}$ & $\begin{array}{l}\text { m-FBF (3) } \\
\text { o-FBF (1) } \\
\text { o-FiBF (3) } \\
\text { p-FBF (4) } \\
\text { p-FiBF (5) }\end{array}$ & $\begin{array}{l}\text { m-FBF (1) } \\
\text { o-FiBF (2) } \\
\text { p-FBF (2) }\end{array}$ \\
\hline o-FiBF & 843 & 826 & 887 & 864 & $\begin{array}{l}\text { m-FBF (1) } \\
\text { o-FBF (4) } \\
\text { o-FiBF (4) } \\
\text { p-FBF (5) } \\
\text { p-FiBF (5) }\end{array}$ & $\begin{array}{c}\text { m-FiBF (1) } \\
\text { p-FBF (2) }\end{array}$ & $\begin{array}{l}\text { m-FBF (1) } \\
\text { m-FiBF (1) } \\
\text { p-FiBF (2) }\end{array}$ & $\begin{array}{l}\text { m-FBF (1) } \\
\text { p-FBF (1) }\end{array}$ \\
\hline p-FiBF & 848 & 941 & 919 & 960 & $\begin{array}{l}\text { m-FiBF (1) } \\
\text { p-FBF (1) }\end{array}$ & None & None & None \\
\hline \multicolumn{9}{|c|}{ Set 5} \\
\hline 6-APDB & 964 & 938 & 963 & 987 & None & None & 5-APDB (1) & None \\
\hline 5-APDB & 908 & 931 & 966 & 992 & None & None & None & None \\
\hline Buphedrone & 940 & 940 & 983 & 975 & Ethcathinone (2) & $\begin{array}{l}\text { Dimethylcath. } \\
\text { (1) }\end{array}$ & None & None \\
\hline Dimethylcathinone & 923 & 949 & 985 & 989 & $\begin{array}{l}\text { Buphedrone (2) } \\
\text { Ethcathinone (1) }\end{array}$ & $\begin{array}{l}\text { Buphedrone (1) } \\
\text { Ethcathinone (1) }\end{array}$ & None & None \\
\hline Ethcathinone & 896 & 892 & 931 & 997 & $\begin{array}{l}\text { Buphedrone (4) } \\
\text { Dimethylcath. } \\
\text { (4) }\end{array}$ & $\begin{array}{c}\text { Buphedrone (5) } \\
\text { Dimethylcath. } \\
(4) \\
\text { 2-MMC (1) } \\
\end{array}$ & None & None \\
\hline Mephedrone & 945 & 877 & 969 & 984 & $\begin{array}{l}\text { Buphedrone (1) } \\
\text { Ethcathinone (2) }\end{array}$ & $\begin{array}{c}\text { Buphedrone (4) } \\
\text { Dimethylcath } \\
\text { (3) } \\
\text { Ethcathinone (1) }\end{array}$ & None & None \\
\hline 2-MMC & 901 & 870 & 982 & 984 & $\begin{array}{l}\text { Buphedrone (3) } \\
\text { Dimethylcath. } \\
\text { (2) } \\
\text { Mephedrone (2) }\end{array}$ & $\begin{array}{l}\text { Buphedrone (5) } \\
\text { Dimethylcath. } \\
\text { (4) }\end{array}$ & None & None \\
\hline MMAI & 881 & 902 & 974 & 988 & None & None & None & None \\
\hline
\end{tabular}

Abbreviations: "Cyclopropyl" is cyclopropyl fentanyl. "Crotonyl" is crotonyl fentanyl. "Methacryl" is methacryl fentanyl.

"Dimethylcath." is dimethylcathinone.

\section{Study 4. Sensitivity}

The calculated limits of detection for all compounds were found to range from $0.12 \mathrm{ng}$ to $4.41 \mathrm{ng}$ which are in line with published LOD values for DART-MS[2]. The specific LODs for each compound are given in Tables 7. LODs are reported in ng since a $1 \mu \mathrm{L}$ volume of solution was used for all experiments.

Table 7. Calculated limits of detection using a $90 \%$ confidence for both instruments. 


\begin{tabular}{|c|c|c|}
\hline \multirow{2}{*}{ Compound } & \multicolumn{2}{|c|}{ LOD (ng) } \\
\hline & Instrument 1 & Instrument 2 \\
\hline Methamphetamine & 0.87 & 0.38 \\
\hline$\alpha$-Pyrrolidinobutiophenone & 0.21 & 1.82 \\
\hline Butylone & 0.12 & 1.40 \\
\hline Ethylone & 4.41 & 1.10 \\
\hline $\begin{array}{c}\alpha- \\
\text { Pyrrolidinovalerophenone }\end{array}$ & 1.14 & 1.59 \\
\hline Phencyclidine & 1.02 & 1.73 \\
\hline Tenocyclidine & 1.07 & 2.71 \\
\hline Nandrolone & 1.79 & 1.46 \\
\hline Cocaine & 0.27 & 1.05 \\
\hline Alprazolam & 1.24 & 0.54 \\
\hline Stanozolol & 0.41 & 0.47 \\
\hline Heroin & 0.54 & 1.74 \\
\hline Furanyl Fentanyl & 1.01 & 0.99 \\
\hline $\begin{array}{l}\text { Furanyl Fentanyl 3- } \\
\text { Furancarboxamide }\end{array}$ & 1.03 & 2.02 \\
\hline 5-Fluoro ADB & 2.37 & 1.61 \\
\hline \multicolumn{3}{|c|}{ Negative Mode } \\
\hline GHB & 1.48 & 0.36 \\
\hline Secobarbital & 1.21 & 1.42 \\
\hline AB-FUBINACA & 2.10 & 0.44 \\
\hline
\end{tabular}

\section{Study 5. Environmental (Solvent) Effects}

For positive mode, compound detection was possible for all three replicates in chloroform, hexane, and methanol. Six compounds (nandrolone decanoate, alprazolam, stanozolol, heroin, furanyl fentanyl, and furanyl fentanyl 3-furancarboxamide) were not detectable in one of the acetone replicates for Instrument 1. Methanol and hexane typically produced the highest abundance peaks with acetone consistently performing worst, as shown in Figure 2. No solvent-related $\mathrm{m} / \mathrm{z}$ drift or formation of adduct species was observed. Chloroform and acetone were found to be largely detrimental to analyte signal, though there are some compound-specific dependences. Similar results were observed in negative mode (Supplemental Figure 10), with detection of all three compounds possible in all solvents (except GHB in chloroform for Instrument 2), and lowest signals obtained in an acetone or chloroform solution. 

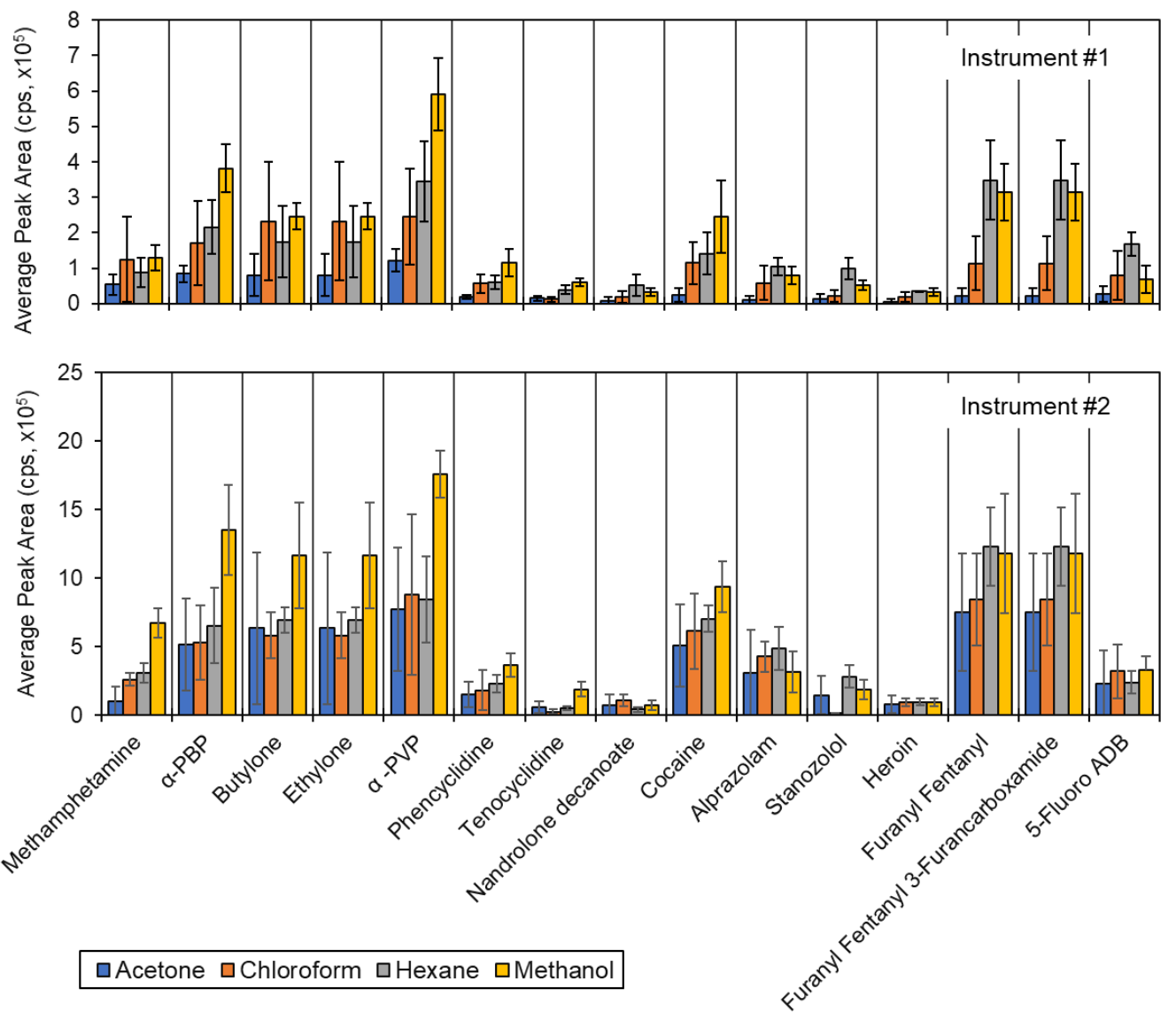

Figure 2. Average peak area as a function of solvent for all compounds analyzed in the positive mode environmental study on Instrument 1 (top) and Instrument 2 (bottom). Error bars represent the standard deviation of three replicate measurements.

\section{Study 6. Non-probative Casework}

During the non-probative casework studies, several opportunities for change were identified that led to modifications in the analytical protocols. The first modification was brought about because it was established that the mass spectra obtained using $+20 \mathrm{~V}$ and $+30 \mathrm{~V}$ orifice 1 voltages were nearly identical except for an increased dimer presence in the $+20 \mathrm{~V}$ spectra. To minimize the dimer contribution, the +30 V orifice 1 spectra were used for analysis of case samples. Second, to minimize issues with the false identification in low intensity spectra, the use of an internal standard was incorporated, as discussed above. Inclusion of tetracaine as an internal standard ensured that the $5 \%$ relative abundance threshold did not cause false identification of noise peaks, which was observed in Study 2, and also provided a mass calibration check standard in each sample. In order for a sample to have a positive identification, the peak corresponding to tetracaine had to also be within the \pm 0.005 Da tolerance and present at or above $5 \%$ relative intensity. 
As demonstrated in the specificity portion of the validation study it was demonstrated that while DARTMS is incapable of providing differentiation of positional isomers, use of the fragment ions can allow for the differentiation of some structural isomers. To assist in the identification process, a series of fragment ion search lists were created for instances where differentiation was possible and were employed in this portion of the study, where appropriate. When the main search list provided multiple results for the same $\mathrm{m} / \mathrm{z}$ value, the fragmentation search lists were loaded concurrently and the sample was re-searched to identify which, if any, of the fragment ions of interest were detected. For some compounds this required the acquisition and searching of the $+60 \mathrm{~V}$ spectra, in addition to the $+30 \mathrm{~V}$ spectra, in order to obtain the necessary fragment ion.

Using the above modifications, a total of 43 samples containing a controlled substance and seven samples containing no controlled substances were analyzed by DART-MS. A summary of these results is shown in Table 8. In 39 of the 43 samples containing a controlled substance, DART-MS was able to correctly identify all substances that were identified by GC-MS. Of the four samples $(1,3,14$, and 42$)$ where not all controlled substances were detected, three correctly identified at least some of the controlled substances and one did not identify any of the controlled substances, a false negative. For the three incomplete results (Samples 3, 14 , and 42), detection of low-concentration compounds that have poorer ionization efficiencies were not obtained at the $5 \%$ threshold. Given the lack of chromatography in DART-MS, competitive ionization can prohibit detection of low concentration compounds when those compounds are more poorly ionized than the major constituents. This is a phenomenon that has been previously documented $[6,10]$ and is something that drug chemists should be aware of, especially for heroin / fentanyl mixtures when heroin is the minor component. For Sample 1, where a false negative was obtained, insufficient amount of material was found to be the likely cause of the missed compound identification. Sample 1 was analyzed as if it was a powder but originated from a counterfeit pharmaceutical tablet. Due to the small amount of material sampled $(<2$ $\mathrm{mg}$ ) the controlled substances were likely below the detection limit of the instrument.

In all seven samples that did not contain controlled substances, no controlled substances were detected by DART-MS. Use of tetracaine as an internal standard was found to assist in correctly identifying negative samples and eliminating false identification of background or noise peaks. The $m / z$ for tetracaine was found to fall within tolerance for all samples. A number of excipients were also able to be identified in the samples. As expected, limitations due to the inability to differentiate isomers precluded definitive identification by DART-MS in some instances. This does not present any limitations in the analysis, but instead, highlights the complementarity of data obtained by DART-MS and GC-MS. 
Table 8. Results of the non-probative casework study (Study 6). For samples where multiple items were identified, individual compounds are listed on separate lines. For the DART-MS result, when multiple potential compounds could be assigned to the same $m / z$ value, they are listed with a vertical line "|" between them. The controlled substances identified by GC-MS are also provided, for comparison.

\begin{tabular}{|c|c|c|}
\hline Sample & DART-MS Result & GC-MS Result \\
\hline 1 & No Compounds Identified & $\begin{array}{l}\text { Fentanyl } \\
\text { Alprazolam } \\
\text { Etizolam }\end{array}$ \\
\hline 2 & Methamphetamine (Frag ID) & Methamphetamine \\
\hline 3 & $\begin{array}{c}-- \\
\text { MDMA } \\
\text { Excipients: Caffeine, Quinine }\end{array}$ & $\begin{array}{l}\text { Heroin } \\
\text { MDMA }\end{array}$ \\
\hline 4 & $\begin{array}{c}\text { Fentanyl | methyl Acetyl Fentanyl | Isofentanyl } \\
\text { Levamisole } \\
\text { Tramadol } \\
\text { Excipients: Phenylpropanamide, Mannitol }{ }^{\dagger}, \text { Procaine, Pindolol }\end{array}$ & $\begin{array}{l}\text { Fentanyl } \\
\text { Levamisole }^{\text {Tramadol }}{ }^{\mathrm{INS}}\end{array}$ \\
\hline 5 & $\begin{array}{l}\text { 4-methyl- } \alpha-\text { PHP (Frag ID) } \\
\text { Excipients: Dextrorphan }\end{array}$ & 4-methyl- $\alpha-P H P$ \\
\hline 6 & MDMA (Frag ID) & MDMA \\
\hline 7 & $\begin{array}{l}\text { No Controlled Substances } \\
\text { Excipients: Mannitol' }\end{array}$ & No Controlled Substances \\
\hline 8 & $\begin{array}{c}\text { Heroin } \\
\text { 6-Monoacetylmorphine } \\
\text { Excipients: Papaverine }\end{array}$ & Heroin \\
\hline 9 & methyl Norfentanyl (Frag ID) & methyl Norfentanyl \\
\hline 10 & Cathinone $m / z .178$ (Frag ID) & 4-Ethylmethcathinone \\
\hline 11 & $\begin{array}{l}\text { Cathinone } m / z 236 \\
\text { Excipient: Caffeine }\end{array}$ & Dibutylone \\
\hline 12 & $\begin{array}{c}\text { Cathinone } m / z 192^{\dagger} \\
\text { Cathinone } m / z 220 \\
\text { Fentanyl | methyl Acetyl Fentanyl | Isofentanyl }\end{array}$ & $\begin{array}{l}\text { 4-Ethylmethcathinone } \\
\text { 4-Methyl- } \alpha \text { - } \\
\text { ethylaminopentiophenone } \\
\text { Fentanyl }\end{array}$ \\
\hline 13 & MMB-FUBINACA $\mid$ MEP-FUBINACA (Frag ID) & MMB-FUBINACA \\
\hline 14 & $\begin{array}{c}\text { Cyclopropyl Fentanyl | Crotonyl Fentanyl | Methacrylfentanyl } \\
\text { Phenyl Fentanyl } \\
--- \\
\text { Excipients: Mannitol, Caffeine }\end{array}$ & $\begin{array}{l}\text { Heroin } \\
\text { Cyclopropyl Fentanyl } \\
\text { Phenyl Fentanyl } \\
\text { Acetylmorphine }\end{array}$ \\
\hline 15 & AB-FUBINACA (isomer) | AB-7-FUBAICA (Frag ID) & $\begin{array}{l}\text { AB-FUBINACA 2-fluorobenzyl } \\
\text { isomer }\end{array}$ \\
\hline 16 & No Controlled Substances & No Controlled Substances \\
\hline 17 & Cathinone $m / z 236$ & Dibutylone \\
\hline 18 & $\begin{array}{l}\text { Acetyl fentanyl | Benzyl fentanyl } \\
\text { Fentanyl | methyl Acetyl fentanyl | isofentanyl } \\
\text { Excipients: Quinine, Mannitol }\end{array}$ & $\begin{array}{l}\text { Acetyl fentanyl } \\
\text { Fentanyl }\end{array}$ \\
\hline 19 & $\begin{array}{c}\text { Heroin } \\
\text { Acetyl fentanyl | Benzyl fentanyl } \\
\text { Fentanyl | methyl Acetyl fentanyl | isofentanyl }\end{array}$ & $\begin{array}{l}\text { Heroin } \\
\text { Acetyl fentanyl }^{\mathrm{INS}} \\
\text { Fentanyl }^{\mathrm{INS}}\end{array}$ \\
\hline
\end{tabular}




\begin{tabular}{|c|c|c|}
\hline & $\begin{array}{c}\text { Fluorobutyryl fentanyl (iso) | Fluoroisobutyryl fent. (iso) } \\
\text { Excipients: Caffeine, Mannitol, Quinine }\end{array}$ & FIBF $^{\text {INS }}$ \\
\hline 20 & $\begin{array}{l}\text { No Controlled Substances } \\
\text { Excipients: Guaidenesin, Quinine }\end{array}$ & No Controlled Substances \\
\hline 21 & $\begin{array}{l}\text { No Controlled Substances } \\
\text { Excipients: Acetaminophen, Xylitol }\end{array}$ & No Controlled Substances \\
\hline 22 & $\begin{array}{c}\text { Fentanyl } \mid \text { methyl Acetyl fentanyl | isofentanyl } \\
\text { XLR11 (isomer) }\end{array}$ & $\begin{array}{l}\text { Fentanyl } \\
\text { XLR11 }\end{array}$ \\
\hline 23 & JWH-201 | JWH-250 | JWH-302 & JWH-250 \\
\hline 24 & JWH-018 & JWH-018 \\
\hline 25 & $\alpha-P V P$ & $\alpha$-PVP \\
\hline 26 & Cathinone $m / z 236$ & Eutylone \\
\hline 27 & $\begin{array}{l}\text { No Controlled Substance } \\
\text { Excipients: Caffeine }\end{array}$ & No Controlled Substance \\
\hline 28 & Cathinone $m / z, 192$ (Frag ID) & Methylethcathinone \\
\hline 29 & $\begin{array}{c}\alpha \text {-PBP | 4-Me-a-PPP | Deschloro-N-ethyl ketamine } \\
\text { 5-Fluoro-AKB48 } \\
\text { Excipients: Mannitol }\end{array}$ & $\begin{array}{c}\alpha-\text {-PBP } \\
\text { 5-Fluoro-AKB48 }\end{array}$ \\
\hline 30 & $\begin{array}{c}\text { Cathinone } m / 2236 \\
\text { JWH-201 | JWH-250 | JWH-302 } \\
\text { Fentanyl | methyl Acetyl fentanyl | isofentanyl }\end{array}$ & $\begin{array}{l}\text { Dibutylone } \\
\text { JWH-250 } \\
\text { Fentanyl }\end{array}$ \\
\hline 31 & Tramadol & Tramadol \\
\hline 32 & JWH-201 | JWH-250 | JWH-302 & JWH-250 \\
\hline 33 & $\begin{array}{c}\text { Heroin } \\
\text { Fentanyl | methyl Acetyl fentanyl | isofentanyl } \\
\text { Fluorobutyryl fentanyl (iso) | Fluoroisobutyryl fent. (iso) } \\
\text { Acetyl fentanyl | Benzyl fentanyl } \\
\text { Excipients: Caffeine }\end{array}$ & $\begin{array}{l}\text { Heroin } \\
\text { Fentanyl } \\
\text { FIBF } \\
\text { Acetyl Fentanyl }{ }^{\mathrm{INS}}\end{array}$ \\
\hline 34 & $\begin{array}{c}\text { Cathinone } m / 2236 \\
\text { Excipients: Caffeine }\end{array}$ & Eutylone \\
\hline 35 & $\begin{array}{c}\text { Fentanyl | methyl Acetyl fentanyl | isofentanyl } \\
\text { Tramadol } \\
\text { Excipients: Phenylpropanamide, Mannitol, Caffeine, Levamisole, } \\
\text { Procaine, Pindolol, Methoxpropamine }\end{array}$ & $\begin{array}{l}\text { Fentanyl } \\
\text { Tramadol }^{\mathrm{NNS}}\end{array}$ \\
\hline 36 & methyl AP-237| AP-238 & AP-238 \\
\hline 37 & $\begin{array}{c}\text { Heroin } \\
\text { 6-Monoacetylmorphine }\end{array}$ & Heroin \\
\hline 38 & $\begin{array}{l}\text { Methyl Fentanyl (Frag ID) } \\
\text { JWH-201 | JWH-250 | JWH-302 }\end{array}$ & $\begin{array}{l}\alpha \text {-Methyl Fentanyl } \\
\text { JWH-250 }\end{array}$ \\
\hline 39 & $\begin{array}{c}\text { Fentanyl | methyl Acetyl fentanyl (iso) } \mid \text { Isofentanyl } \\
\text { Excipient: Quinine, Caffeine, Xylazine }\end{array}$ & Fentanyl \\
\hline 40 & $\begin{array}{l}\text { Cyclopropyl Fentanyl | Crotonyl Fentanyl | Methacrylfentanyl } \\
\text { Cathinone } m / z 212\end{array}$ & $\begin{array}{l}\text { Cyclopropyl Fentanyl } \\
\text { 4-Chloroethcathinone }\end{array}$ \\
\hline 41 & $\begin{array}{l}\text { No Controlled Substances } \\
\text { Excipients: Mannitol }\end{array}$ & No Controlled Substances \\
\hline 42 & $\begin{array}{c}\text { Heroin } \\
\text { Noscapine }^{4} \\
\text { Fentanyl | methyl Acetyl fentanyl (iso) | Isofentanyl } \\
\text { Acetyl fentanyl | Benzyl fentanyl } \\
\text {--- } \\
\text { Fluorobutyryl fentanyl (iso) | Fluoroisobutyryl fent. (iso) } \\
\text { 6-Monoacetylmorphine }\end{array}$ & $\begin{array}{l}\text { Heroin } \\
\text { Noscapine } \\
\text { Fentanyl }^{\mathrm{INS}} \\
\text { Acetyl Fentanyl }^{\mathrm{INS}} \\
\text { Cocaine }^{\mathrm{INS}} \\
\text { FIBF }^{\mathrm{INS}}\end{array}$ \\
\hline
\end{tabular}




\begin{tabular}{|c|c|c|}
\hline & Excipients: Caffeine & \\
\hline 43 & Methylone (isomer) (Frag ID) & Methylone \\
\hline 44 & N-methyl Cyclopropyl norfentanyl & Methyl Cyclopropyl norfentanyl \\
\hline 45 & $\begin{array}{c}\text { No Controlled Substances } \\
\text { Excipients: Lidcocaine, Quinine }\end{array}$ & No Controlled Substances \\
\hline 46 & Cathinone $m / z$, 192 & Methylethcathinone \\
\hline 47 & JWH-018 & JWH-018 \\
& MDPV & MDPV \\
\hline 48 & Ethylpentylone | Dimethylpentylone | Tertylone (Frag ID) & N-Ethyl pentylone \\
\hline 49 & MMB-FUBINACA | MEP-FUBINACA (Frag ID) & FUB-AMB \\
\hline 50 & $\alpha$-PVP & $\alpha$-PVP \\
\hline
\end{tabular}

$\dagger$ Detected only on Instrument 1.

${ }^{4}$ Detected only on Instrument 2.

INS GC-MS result had compound present but at an insufficient level to report.

(Frag ID) Required the use of an additional fragment ion search list to differentiate from other compounds at same $\mathrm{m} / \mathrm{z}$, value.

-- Compound was detected in GC-MS but not by DART-MS.

(iso) Indicates there are multiple isomeric species present that DART-MS cannot distinguish.

\section{Study 7. Method Robustness}

After completing the method robustness study with additional chemists on both instruments, no analystdependent issues were identified. The $m / z$ values corresponding to all components were found to be within the \pm 0.005 Da tolerance specified for all replicates from all seven days of analysis. The standard deviations from the theoretical $\mathrm{m} / \mathrm{z}$ values ranged from $\pm 0.0006 \mathrm{Da}$ to $\pm 0.0024 \mathrm{Da}$ (or $\pm 0.6 \mathrm{mDa}$ to $\pm 2.4 \mathrm{mDa}$ ). The coefficient of variation was found to be at or below $0.007 \%$ for all compounds. Supplemental Tables 8 and 9 show the summary results for the positive mode while Supplemental Table 10 shows the results for negative mode. PEG calibration residuals were again found to be acceptable and ranged from $6.0 \times 10^{-13}$ to $1.2 \times 10^{-12}$ for positive mode. For negative mode, all method robustness datafiles were calibrated using multipoint $\mathrm{m} / \mathrm{z}$ drift compensation against a calibration file with a residual of $1.7 \times 10^{-13}$. As in Study 2, methanol blanks in positive mode for several days produced low-intensity peaks with a similar $m / z$ value to cocaine but were at or below the level of background noise. No peaks at $\mathrm{m} / \mathrm{z}$ values of interest were present in the negative mode methanol blanks.

\section{Conclusions}

This work provides a template validation plan that can be adapted by other laboratories who are bringing DART-MS or other ambient ionization mass spectrometry tools online. In addition to the template, the Supplemental Information provides worksheets that laboratories can leverage to assist in the processing and collation of data. Completion of the validation studies on two newly delivered instruments showed they were fit for casework. As expected, isomeric differentiation is not always possible by DART-MS given the lack of chromatography. In addition, it was found that the utilization of an internal standard for casework analysis eliminated the false identification of low-intensity noise peaks in spectra without detectable compounds. The goal of this study was to provide an additional resource to chemists that are focusing on 
adopting new technology into their workflow. Current efforts are looking at the validation of a variation of DART-MS, thermal desorption (TD-DART-MS), for the qualitative analysis of seized drugs.

\section{Disclaimers}

Certain commercial products are identified in order to adequately specify the procedure; this does not imply endorsement or recommendation by NIST, nor does it imply that such products are necessarily the best available for the purpose.

Certain commercial products are identified in order to adequately specify the procedure; this does not imply endorsement or recommendation by the Maryland State Police, nor does it imply that such products are necessarily the best available for the purpose.

A portion of this work was supported by Award No. 2018-DU-BX-0165, awarded by the National Institute of Justice, Office of Justice Programs, U.S. Department of Justice. The opinions, findings, and conclusions or recommendations expressed in this publication/program/exhibition are those of the author(s) and do not necessarily reflect those of the Department of Justice.

\section{References}

[1] R.R. Steiner, Use of DART-TOF-MS for Screening Drugs of Abuse, in: R.A. Musah (Ed.), Analysis of Drugs of Abuse, Springer, New York, NY, 2018: pp. 59-68. https://doi.org/10.1007/978-1-4939-8579-1_5.

[2] E. Sisco, T.P. Forbes, Forensic applications of DART-MS: A review of recent literature, Forensic Chemistry. 22 (2021) 100294. https://doi.org/10.1016/j.forc.2020.100294.

[3] J.H. Gross, Direct analysis in real time--a critical review on DART-MS, Anal Bioanal Chem. 406 (2014) 63-80. https://doi.org/10.1007/s00216-013-7316-0.

[4] M.J. Pavlovich, B. Musselman, A.B. Hall, Direct analysis in real time-Mass spectrometry (DART-MS) in forensic and security applications, Mass Spec Rev. (2016) n/a-n/a. https://doi.org/10.1002/mas.21509.

[5] R.R. Steiner, R.L. Larson, Validation of the direct analysis in real time source for use in forensic drug screening, J. Forensic Sci. 54 (2009) 617-622. https://doi.org/10.1111/j.15564029.2009.01006.x.

[6] E. Sisco, J. Verkouteren, J. Staymates, J. Lawrence, Rapid detection of fentanyl, fentanyl analogues, and opioids for on-site or laboratory based drug seizure screening using thermal desorption DART-MS and ion mobility spectrometry, Forensic Chemistry. 4 (2017) 108115. https://doi.org/10.1016/j.forc.2017.04.001.

[7] K.L. Fowble, J.R.E. Shepard, R.A. Musah, Identification and classification of cathinone unknowns by statistical analysis processing of direct analysis in real time-high resolution 
mass spectrometry-derived "neutral loss" spectra, Talanta. 179 (2018) 546-553. https://doi.org/10.1016/j.talanta.2017.11.020.

[8] E.A. Prokudina, J. Prchalová, E. Vyšatová, M. Kuchař, A. Rajchl, O. Lapčík, Analysis of anabolic androgenic steroids by direct analysis in real time ionization with time-of-flight mass spectrometry, International Journal of Mass Spectrometry. 392 (2015) 28-33. https://doi.org/10.1016/j.ijms.2015.08.022.

[9] J.L. Easter, R.R. Steiner, Pharmaceutical identifier confirmation via DART-TOF, Forensic Science International. 240 (2014) 9-20. https://doi.org/10.1016/j.forsciint.2014.03.009.

[10] E.L. Robinson, E. Sisco, Detection of Brodifacoum and other Rodenticides in Drug Mixtures using Thermal Desorption Direct Analysis in Real Time Mass Spectrometry (TDDART-MS), J. Forensic Sci. 64 (2019) 1026-1033. https://doi.org/10.1111/15564029.13978.

[11] Mass Spectrometry Data Center, NIST, (n.d.). https://chemdata.nist.gov/ (accessed August 26, 2020).

[12] E. Sisco, A.S. Moorthy, L.M. Watt, Creation and Release of an Updated NIST DARTMS Forensics Database, J. Am. Soc. Mass Spectrom. 32 (2021) 685-689. https://doi.org/10.1021/jasms.0c00416.

[13] DART Mass Spectrometry for Forensic Analysis - A Technology Transition Workshop, National Institute of Justice. (n.d.). https://nij.ojp.gov/library/publications/dart-massspectrometry-forensic-analysis-technology-transition-workshop (accessed June 4, 2020).

[14] christina.robinson@nist.gov, FORENSICS@NIST 2020, NIST. (2020). https://www.nist.gov/news-events/events/2020/11/forensicsnist-2020 (accessed June 16, 2021).

[15] Y. Dong, Direct Analysis in Real Time Mass Spectrometry: Principles and Practices of DART-MS, John Wiley \& Sons, 2018.

[16] M. Domin, R. Cody, Ambient Ionization Mass Spectrometry, Royal Society of Chemistry, 2014.

[17] Kei Zaitsu, ed., Ambient Ionization Mass Spectrometry in Life Sciences - 1st Edition, 1st ed., Elsevier, 2019. https://www.elsevier.com/books/ambient-ionization-mass-spectrometryin-life-sciences/zaitsu/978-0-12-817220-9 (accessed June 4, 2020).

[18] R.A. Musah, ed., Analysis of Drugs of Abuse, Humana Press, 2018. https://doi.org/10.1007/978-1-4939-8579-1.

[19] E. Sisco, A. Burns, Templates for the Implementation of DART-MS for Seized Drug Analysis, (2021) 5 files, 3 MB. https://doi.org/10.18434/MDS2-2424.

[20] E. Sisco, A. Burns, E. Schneider, I. Ikpeama, Evaluation of Internal Standard Inclusion for Qualitative Analysis of Seized Drugs using DART-MS, Unpublished Work. (n.d.).

[21] S.E. Stein, An integrated method for spectrum extraction and compound identification from gas chromatography/mass spectrometry data, J. Am. Soc. Mass Spectrom. 10 (1999) 770-781. https://doi.org/10.1021/jasms.8b01368.

[22] N.A. Heckert, Limits of Detection - ASTM E2677, NIST. (2018). https://www.nist.gov/services-resources/software/limits-detection-astm-e2677 (accessed June 17, 2019).

[23] N.A. Heckert, R.M. Verkouteren, K. Kwiatek, Web-Based Calculator for ASTM E2677 Limits of Detection, in: M.J. Brisson (Ed.), Detection Limits in Air Quality and Environmental Measurements, ASTM International, 100 Barr Harbor Drive, PO Box C700, 
West Conshohocken, PA 19428-2959, 2019: pp. 49-59.

https://doi.org/10.1520/STP161820180078. 


\section{Supplemental Information for: A Template for the Validation of DART-MS for Qualitative Seized Drugs Analysis}

Edward Sisco ${ }^{\mathrm{a}}$, Amber Burns ${ }^{\mathrm{b}}$, Elizabeth Schneider ${ }^{\mathrm{b}}$, Laurel Bobka $^{\mathrm{b}}$, Ikenna Ikpeama ${ }^{\mathrm{b}}$

${ }^{a}$ National Institute of Standards and Technology, Gaithersburg, MD, USA

${ }^{b}$ Maryland State Police Forensic Sciences Division, Pikesville, MD, USA

For Submission To: Forensic Chemistry

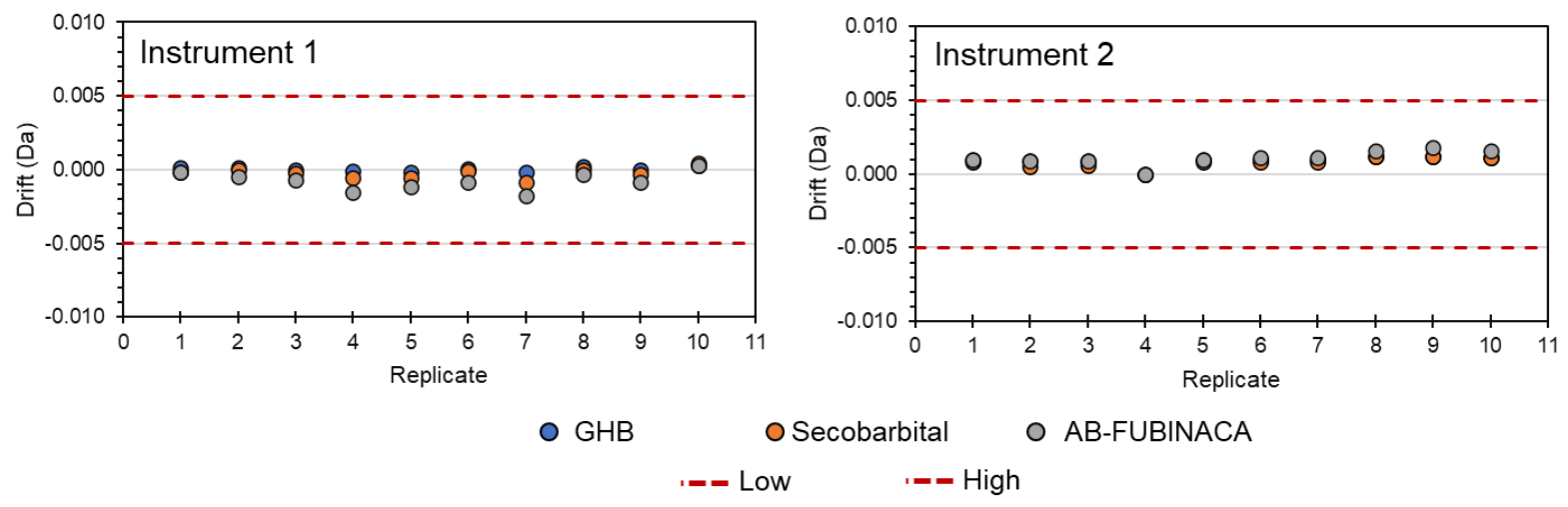

Supplemental Figure 1. Results from the negative mode accuracy and precision study (Study 1) for Instrument 1 (left) and Instrument 2 (right). The theoretical $\mathrm{m} / \mathrm{z}$ values corresponding to this data can be found in Table 2 of the manuscript. The red dotted lines indicate the high and low bounds of the allowable drift from the theoretical $m / z$ values.
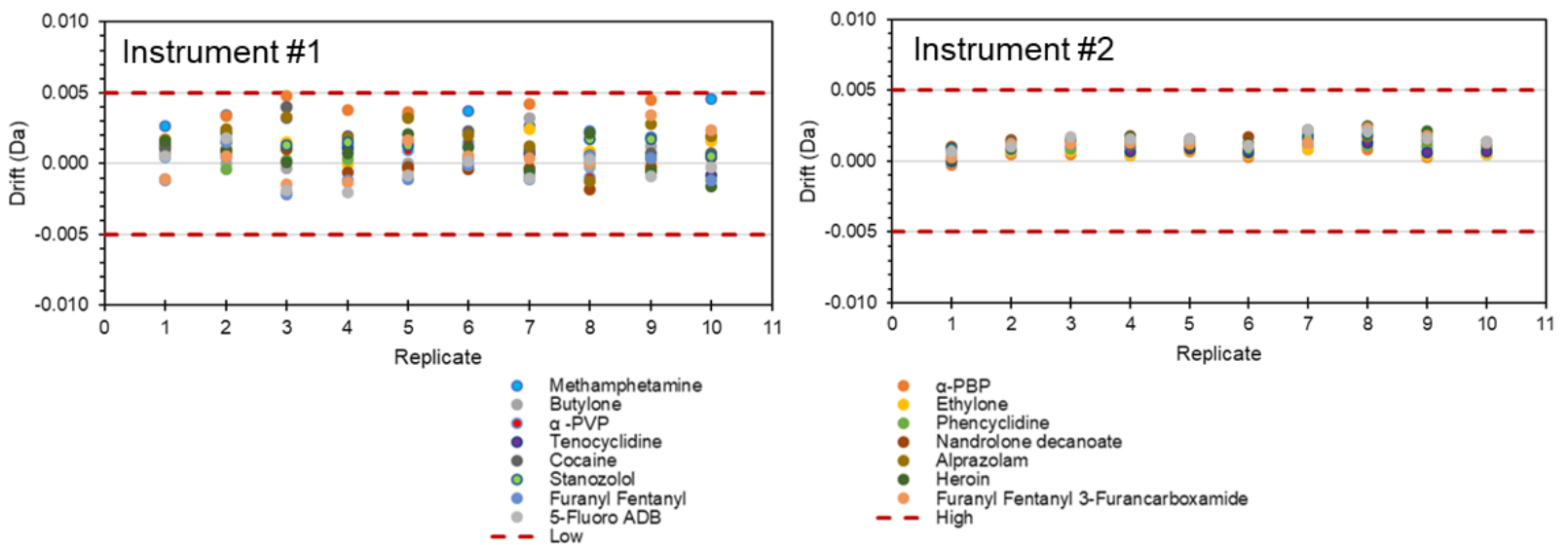

Supplemental Figure 2. Results from the $+30 \mathrm{~V}$ spectra for the single component accuracy study (Study 1) in positive mode for Instrument 1 (left) and Instrument 2 (right). The theoretical $\mathrm{m} / \mathrm{z}$ values corresponding to this data can be found in Supplemental Table 1. The red dotted lines indicate the high and low bounds of the allowable drift from the theoretical $\mathrm{m} / \mathrm{z}$ values. 

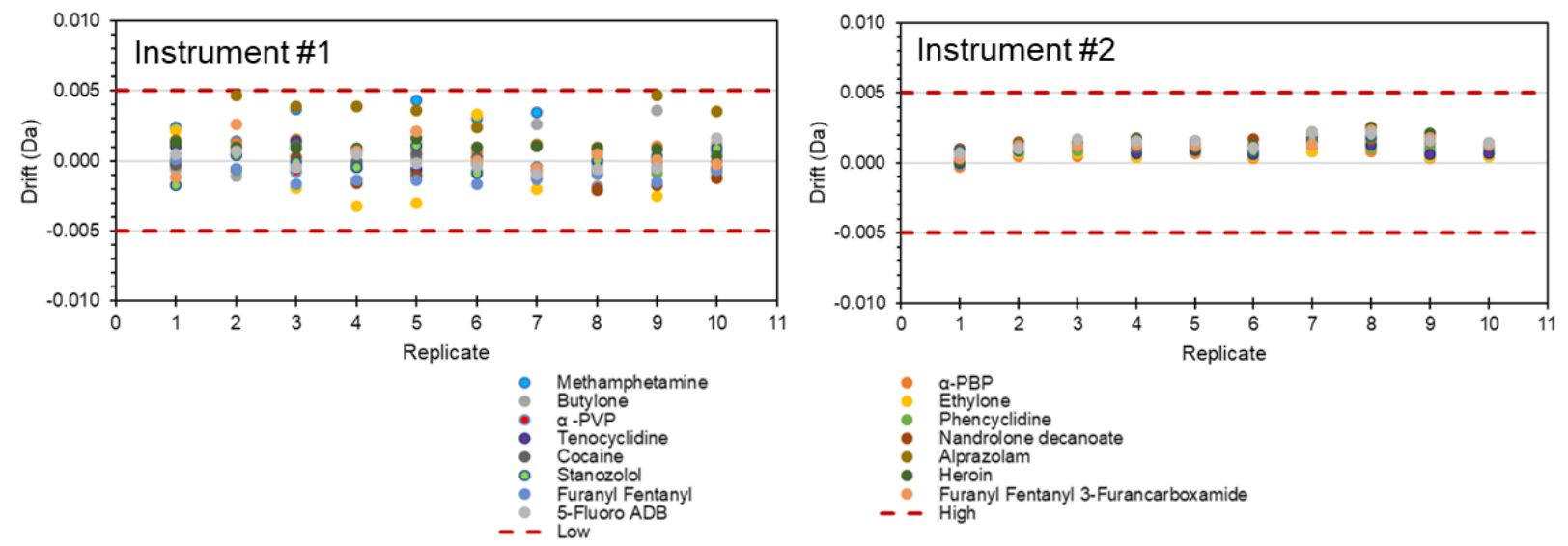

Supplemental Figure 3. Results from the $+60 \mathrm{~V}$ spectra for the single component accuracy study (Study 1) in positive mode for Instrument 1 (left) and Instrument 2 (right). The theoretical $\mathrm{m} / \mathrm{z}$ values corresponding to this data can be found in Supplemental Table 1. The red dotted lines indicate the high and low bounds of the allowable drift from the theoretical $\mathrm{m} / \mathrm{z}$ values.
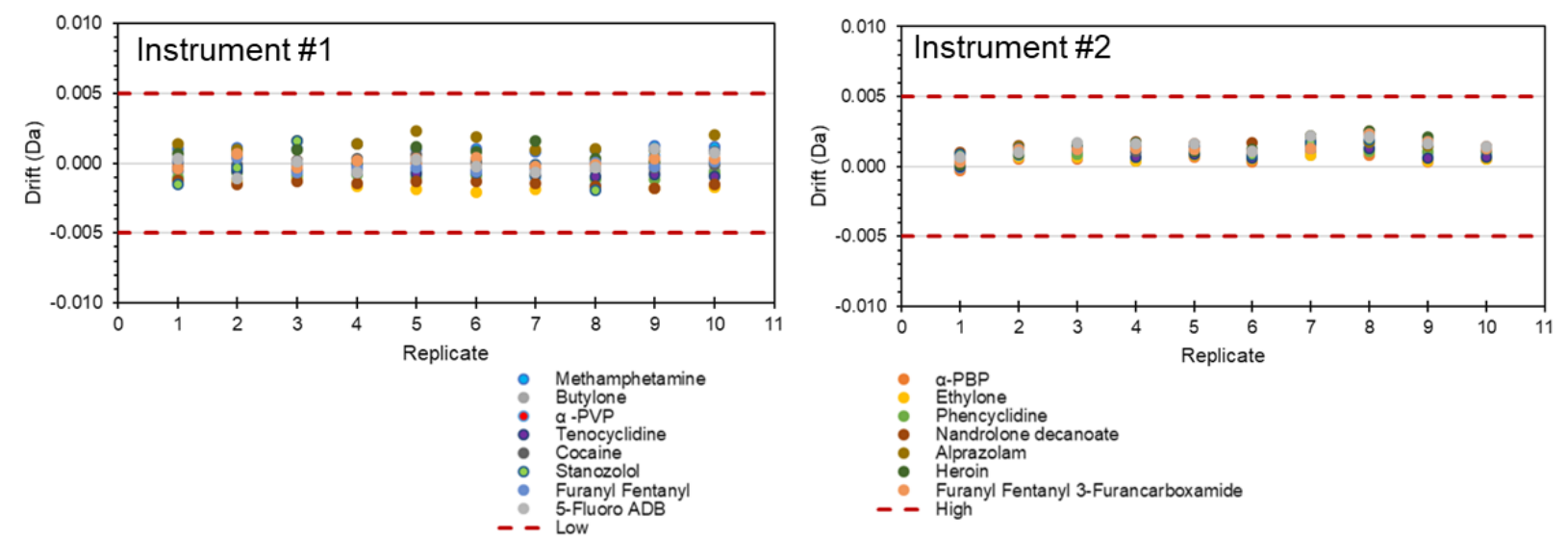

Supplemental Figure 4. Results from the $+90 \mathrm{~V}$ spectra for the single component accuracy study (Study 1) in positive mode for Instrument 1 (left) and Instrument 2 (right). The theoretical $\mathrm{m} / \mathrm{z}$ values corresponding to this data can be found in Supplemental Table 1. The red dotted lines indicate the high and low bounds of the allowable drift from the theoretical $\mathrm{m} / \mathrm{z}$ values. 

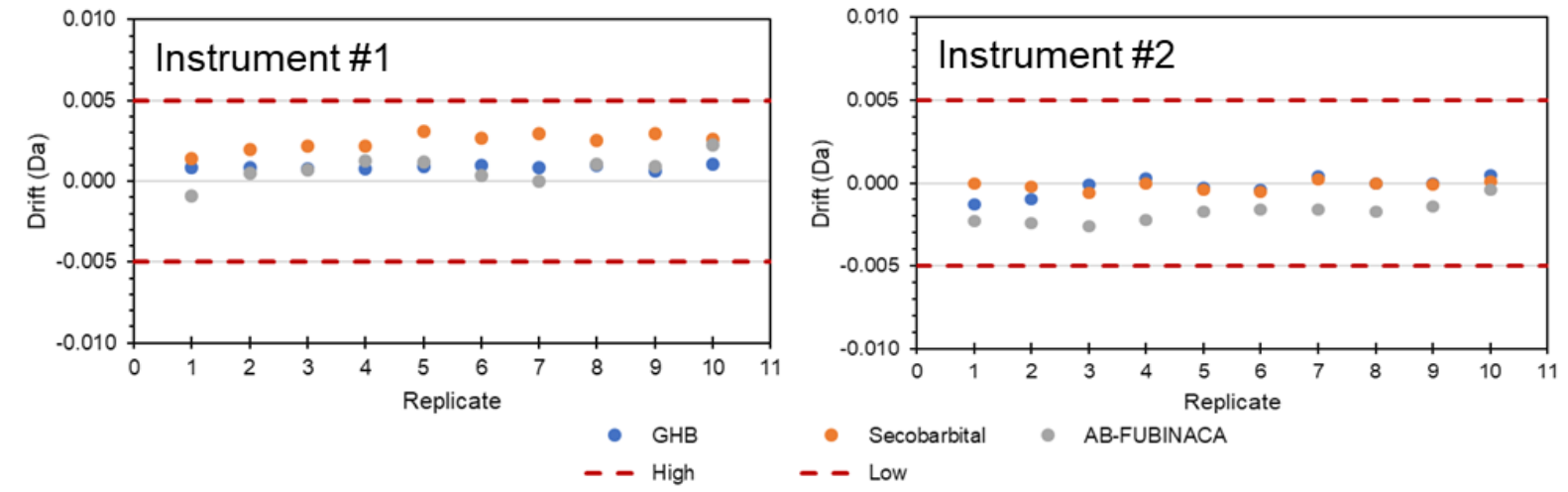

Supplemental Figure 5. Results from the -30V spectra for the single component accuracy study (Study 1) in negative mode for Instrument 1 (left) and Instrument 2 (right). The theoretical $\mathrm{m} / \mathrm{z}$ values corresponding to this data can be found in Supplemental Table 2. The red dotted lines indicate the high and low bounds of the allowable drift from the theoretical $\mathrm{m} / \mathrm{z}$ values.
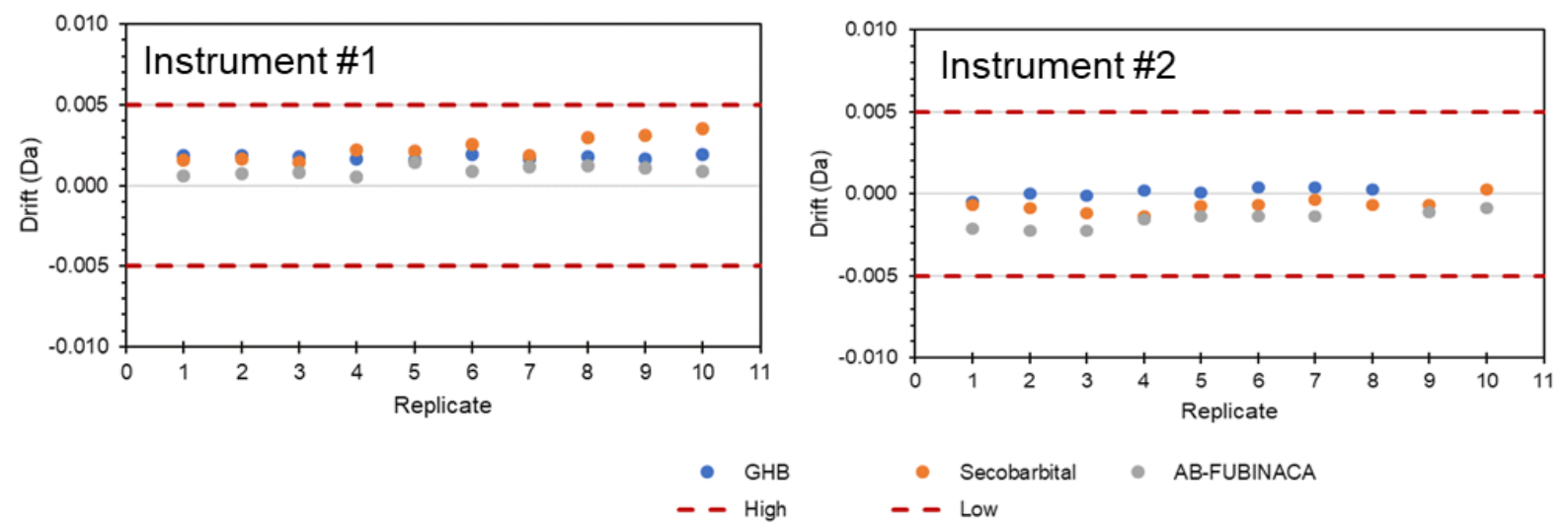

Supplemental Figure 6. Results from the $-60 \mathrm{~V}$ spectra for the single component accuracy study (Study 1) in negative mode for Instrument 1 (left) and Instrument 2 (right). The theoretical $\mathrm{m} / \mathrm{z}$ values corresponding to this data can be found in Supplemental Table 2. The red dotted lines indicate the high and low bounds of the allowable drift from the theoretical $\mathrm{m} / \mathrm{z}$ values. 

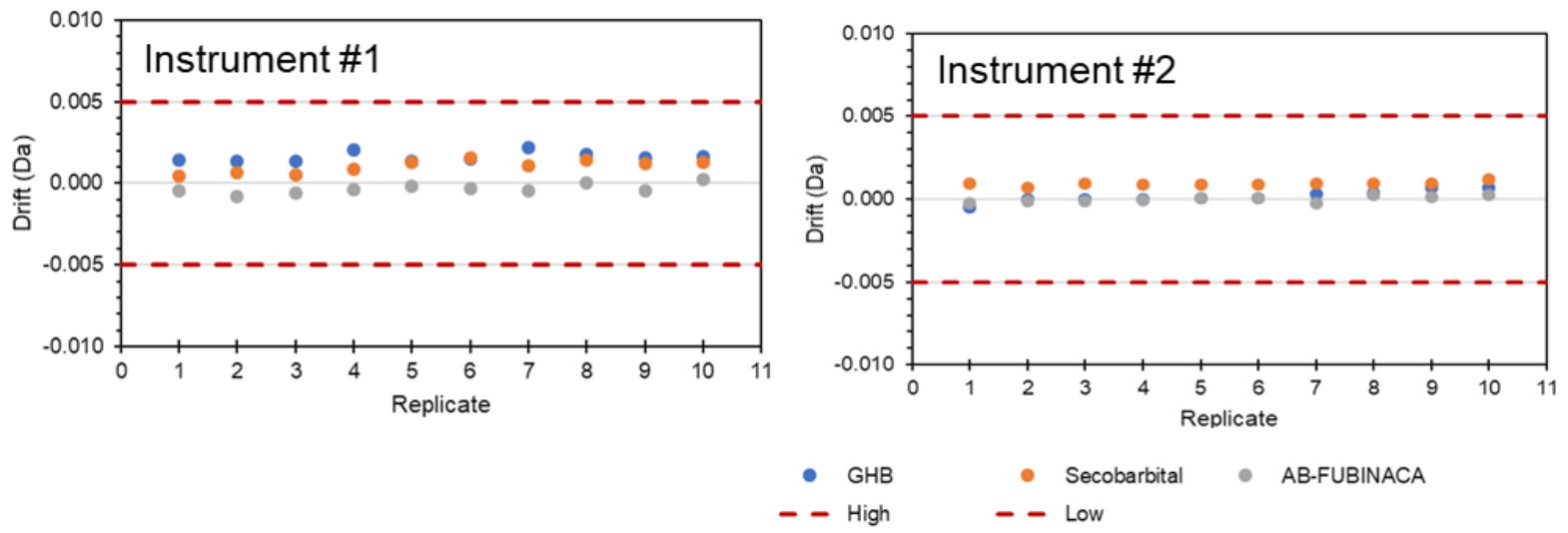

Supplemental Figure 7. Results from the -90V spectra for the single component accuracy study (Study 1) in negative mode for Instrument 1 (left) and Instrument 2 (right). The theoretical $\mathrm{m} / \mathrm{z}$ values corresponding to this data can be found in Supplemental Table 2. The red dotted lines indicate the high and low bounds of the allowable drift from the theoretical $\mathrm{m} / \mathrm{z}$ values. 


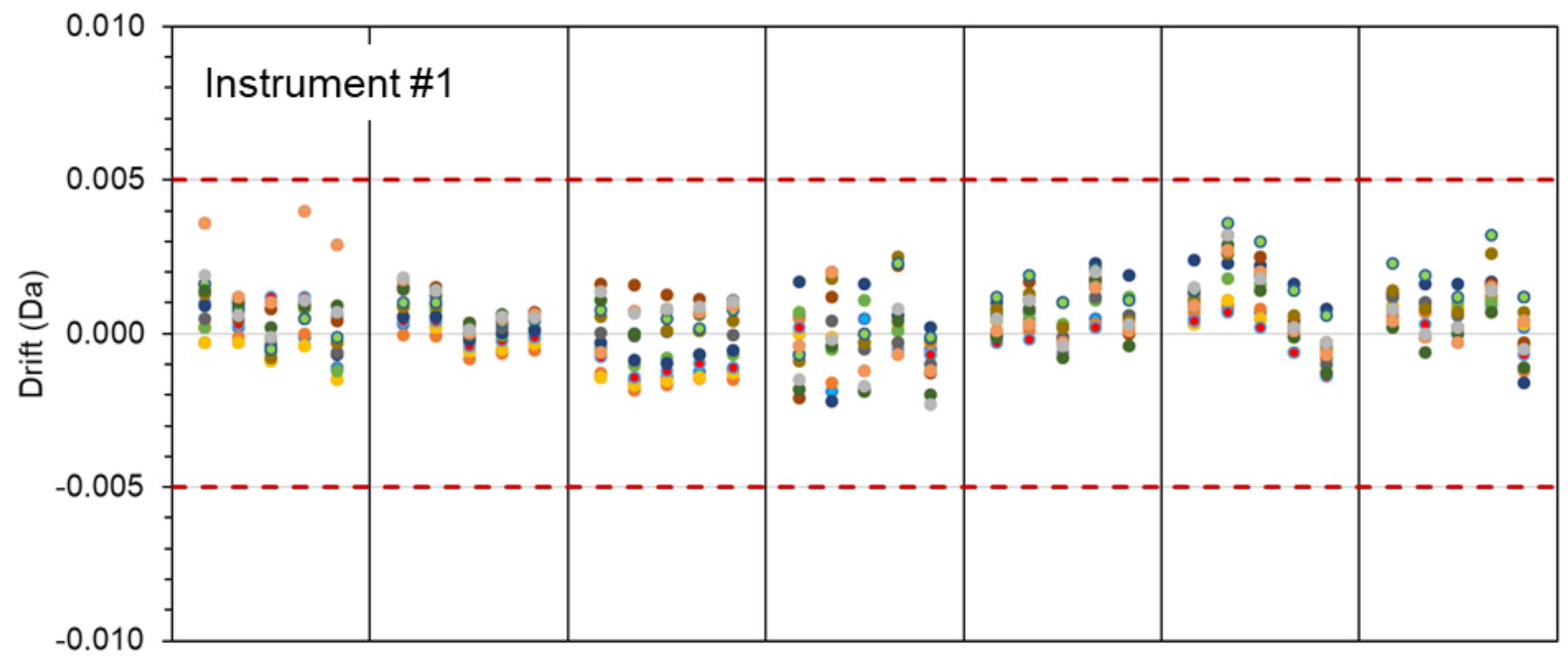

$\begin{array}{lllllll}\text { Set } 1 & \text { Set } 2 & \text { Set } 3 & \text { Set } 4 & \text { Set } 5 & \text { Set } 6 & \text { Set } 7\end{array}$

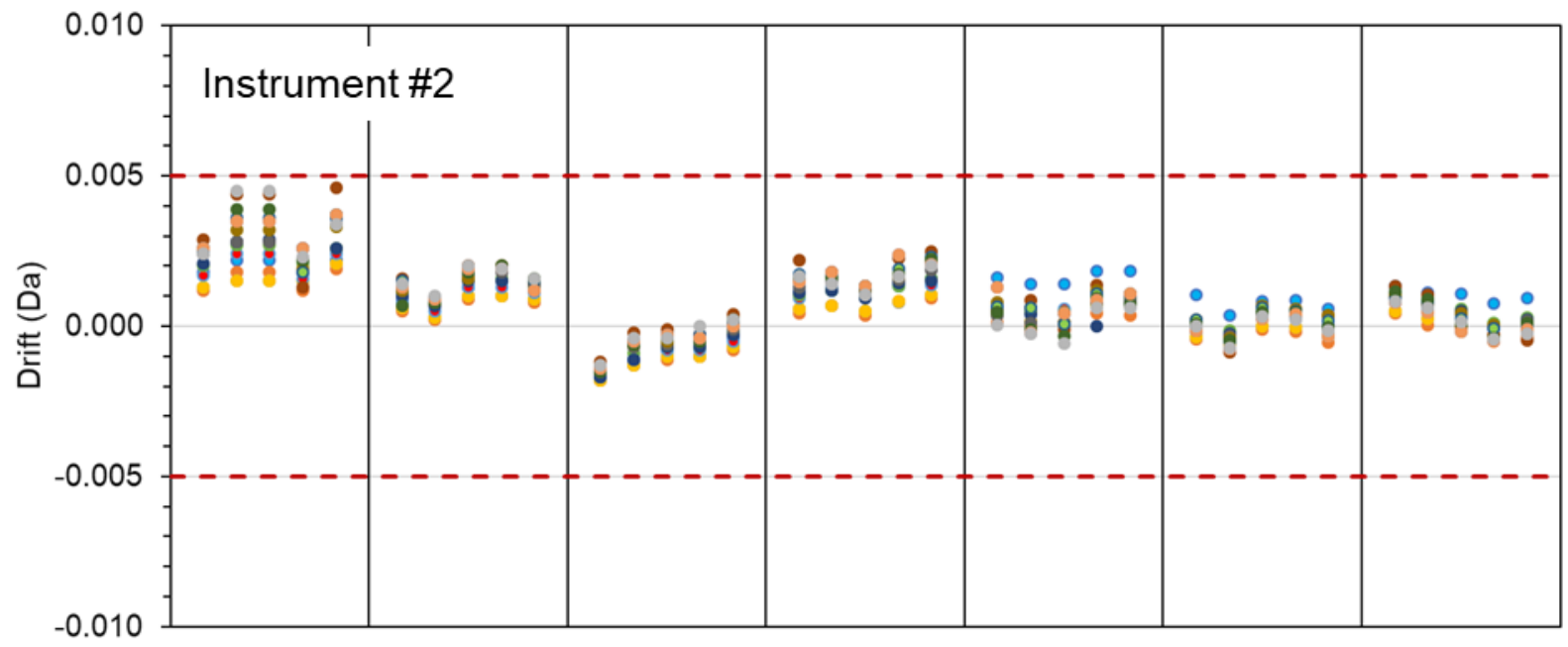
- Methamphetamine
- Butylone
- a-PVP
- Tenocyclidine
- Cocaine
- Stanozolol
- Furanyl Fentanyl
- 5-Fluoro ADB
- - Low
- a-PBP
- Ethylone
- Phencyclidine
- Nandrolone decanoate
- Alprazolam
- Heroin
- Furanyl Fentanyl 3-Furancarboxamide
- - High

Supplemental Figure 8. Results from the positive mode reproducibility study (Study 2) for Instrument 1 (top) and Instrument 2 (bottom). The red dotted lines indicate the high and low bounds of the allowable $\mathrm{m} / \mathrm{z}$ drift from the theoretical $\mathrm{m} / \mathrm{z}$ values. 


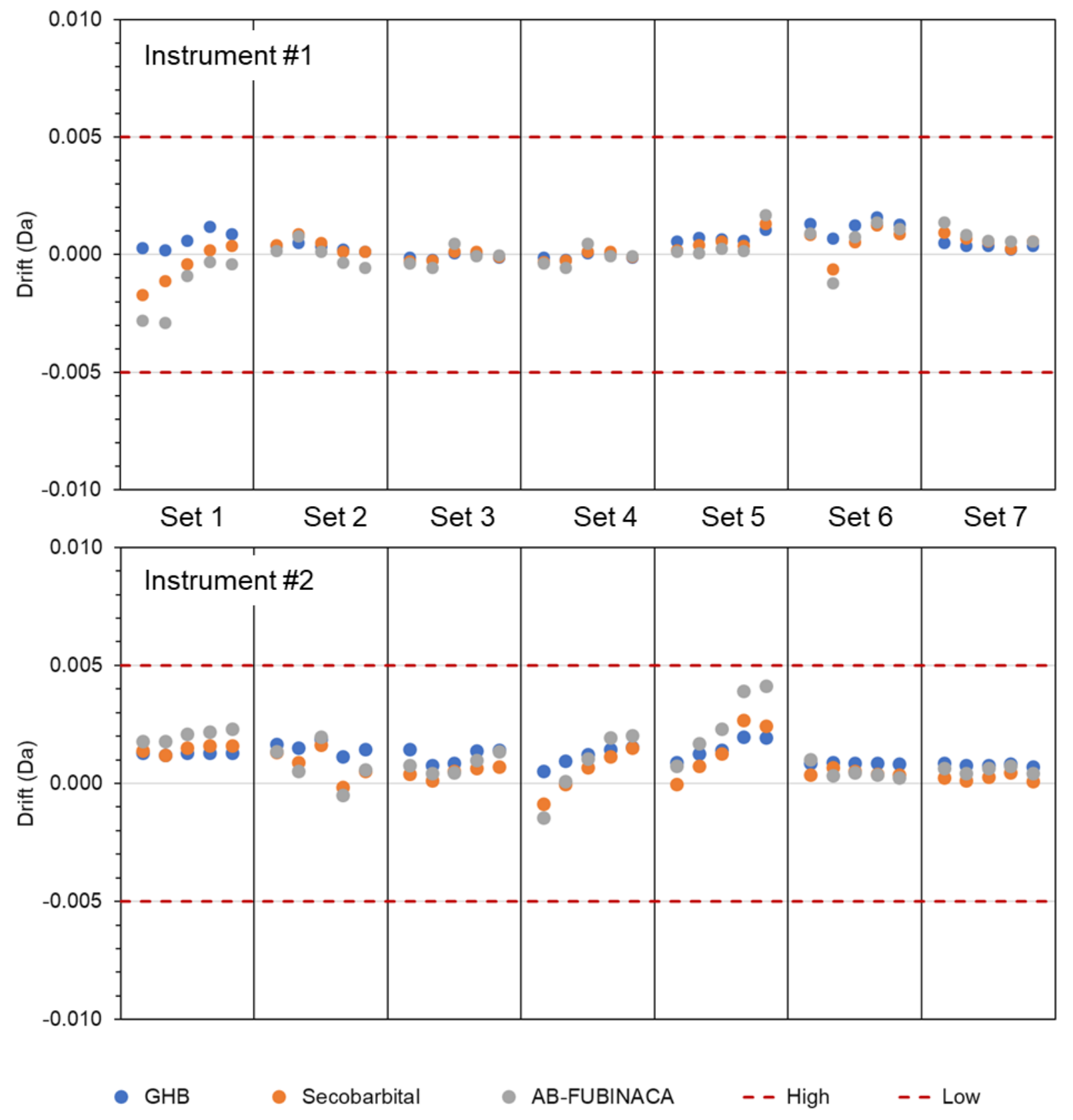

Supplemental Figure 9. Results from the negative mode reproducibility study (Study 2) for Instrument 1 (top) and Instrument 2 (bottom). The red dotted lines indicate the high and low bounds of the allowable $\mathrm{m} / \mathrm{z}$ drift from the theoretical $\mathrm{m} / \mathrm{z}$ values. 

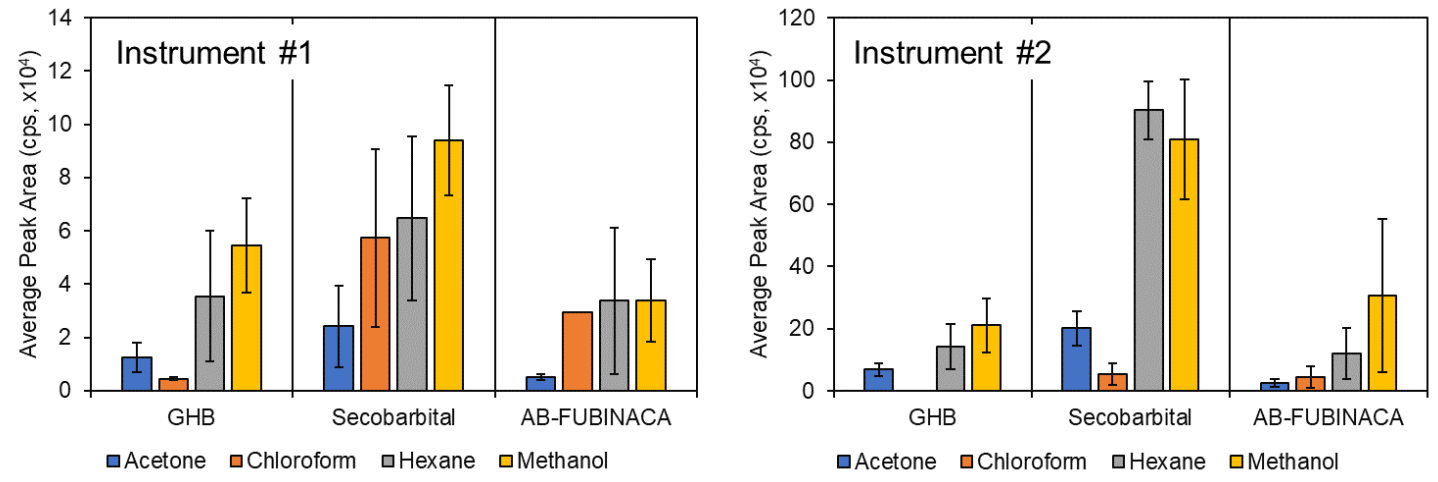

Supplemental Figure 10. Average peak area as a function of solvent (colored bars) for all compounds analyzed in the negative mode study (Study 5) on Instrument 1 (left) and Instrument 2 (right). Error bars represent the standard deviation of triplicate measurements

Supplemental Table 1 List of theoretical $\mathrm{m} / z$ values used for $+30,+60,+90 \mathrm{~V}$ positive mode accuracy and precision studies (Study 1).

\begin{tabular}{|c|c|c|c|}
\hline & $\begin{array}{c}+30 \vee m / z \\
\text { Value }\end{array}$ & $\begin{array}{c}+60 \vee m / z \\
\text { Value }\end{array}$ & $\begin{array}{c}+90 \vee m / z \\
\text { Value }\end{array}$ \\
\hline Methamphetamine & 150.1277 & 91.0542 & 65.0386 \\
\hline$\alpha-P B P$ & 218.1539 & 147.0804 & 91.0542 \\
\hline Butylone & 222.1124 & 174.0913 & 105.0699 \\
\hline Ethylone & 222.1124 & 174.0931 & 91.0542 \\
\hline$\alpha-P V P$ & 232.1695 & 161.0961 & 91.0542 \\
\hline Phencyclidine & 244.2059 & 159.1168 & 86.0964 \\
\hline Tenocyclidine & 250.1624 & 166.1590 & 86.0964 \\
\hline Nandrolone decanoate & 429.3363 & 257.1900 & 91.0542 \\
\hline Cocaine & 304.1543 & 182.1176 & 119.0491 \\
\hline Alprazolam & 309.0901 & 309.0901 & 281.0714 \\
\hline Stanozolol & 329.2587 & 311.2482 & 311.2482 \\
\hline Heroin & 370.1649 & 328.1543 & 268.1332 \\
\hline Furanyl Fentanyl & 375.2067 & 188.1434 & 105.0699 \\
\hline $\begin{array}{l}\text { Furanyl Fentanyl 3- } \\
\text { Furancarboxamide }\end{array}$ & 375.2067 & 188.1434 & 105.0699 \\
\hline 5-Fluoro ADB & 378.2187 & 318.1976 & 233.1085 \\
\hline
\end{tabular}

Supplemental Table 2 List of theoretical $\mathrm{m} / \mathrm{z}$ values used for $-30,-60,-90 \mathrm{~V}$ negative mode accuracy and precision studies (Study 1).

\begin{tabular}{|l|c|c|c|}
\hline & $\begin{array}{c}+\mathbf{3 0 ~ V ~} \mathbf{~} / \mathbf{z} \\
\text { Value }\end{array}$ & $\begin{array}{c}\mathbf{+ 6 0 ~ V ~} \mathbf{~} / \mathbf{z} \\
\text { Value }\end{array}$ & $\begin{array}{c}\mathbf{+ 9 0 ~} \mathbf{~} \mathbf{~ m} / \mathbf{z} \\
\text { Value }\end{array}$ \\
\hline GHB & 103.0390 & 85.0284 & 85.0284 \\
\hline Secobarbital & 237.1234 & 197.0921 & 110.0964 \\
\hline AB-FUBINACA & 367.1565 & 225.0822 & 141.0659 \\
\hline
\end{tabular}


Supplemental Table 3. Summary results for the reproducibility studies (Study 2) for Instrument 2.

\begin{tabular}{|c|c|c|c|c|c|c|}
\hline & $\begin{array}{c}\text { Theoretical } \\
\mathrm{m} / \mathrm{z}\end{array}$ & $\begin{array}{c}\text { Minimum } \\
\mathrm{m} / \mathrm{z}\end{array}$ & $\begin{array}{c}\text { Maximum } \\
\mathrm{m} / \mathrm{z}\end{array}$ & $\begin{array}{c}\text { Average } \\
\mathrm{m} / \mathrm{z}\end{array}$ & $\begin{array}{l}\text { Standard } \\
\text { Deviation } \\
\end{array}$ & $\begin{array}{l}\text { Coefficient of } \\
\text { Variation (\%) } \\
\end{array}$ \\
\hline \multicolumn{7}{|c|}{ Positive Ionization Mode } \\
\hline Methamphetamine & 150.1277 & 150.1262 & 150.1299 & 150.1287 & 0.0009 & 0.0006 \\
\hline$\alpha-\mathrm{PBP}$ & 218.1539 & 218.1521 & 218.1558 & 218.1541 & 0.0009 & 0.0004 \\
\hline Butylone & 222.1124 & 222.1106 & 222.1145 & 222.1127 & 0.0009 & 0.0004 \\
\hline Ethylone & 222.1124 & 222.1106 & 222.1145 & 222.1127 & 0.0009 & 0.0004 \\
\hline$\alpha-P V P$ & 232.1695 & 232.1678 & 232.1719 & 232.1701 & 0.0010 & 0.0004 \\
\hline Phencyclidine & 244.2059 & 244.2043 & 244.2086 & 244.2067 & 0.0010 & 0.0004 \\
\hline Tenocyclidine & 250.1624 & 250.1607 & 250.1653 & 250.1631 & 0.0010 & 0.0004 \\
\hline Nandrolone decanoate & 429.3363 & 429.3351 & 429.3409 & 429.3374 & 0.0014 & 0.0003 \\
\hline Cocaine & 304.1543 & 304.1528 & 304.1577 & 304.1551 & 0.0011 & 0.0004 \\
\hline Alprazolam & 309.0901 & 309.0887 & 309.0934 & 309.0911 & 0.0011 & 0.0004 \\
\hline Stanozolol & 329.2587 & 329.2573 & 329.2623 & 329.2597 & 0.0012 & 0.0004 \\
\hline Heroin & 370.1649 & 370.1634 & 370.1688 & 370.1658 & 0.0013 & 0.0004 \\
\hline Furanyl Fentanyl & 375.2067 & 375.2053 & 375.2104 & 375.2076 & 0.0013 & 0.0003 \\
\hline $\begin{array}{l}\text { Furanyl Fentanyl 3- } \\
\text { Furancarboxamide }\end{array}$ & 375.2067 & 375.2053 & 375.2104 & 375.2076 & 0.0013 & 0.0003 \\
\hline 5-Fluoro ADB & 378.2187 & 378.2174 & 378.2232 & 378.2196 & 0.0014 & 0.0004 \\
\hline \multicolumn{7}{|c|}{ Negative Ionization Mode } \\
\hline AB-FUBINACA & 103.0390 & 103.0395 & 103.0410 & 103.0402 & 0.0004 & 0.0004 \\
\hline GHB & 237.1234 & 237.1225 & 237.1261 & 237.1241 & 0.0007 & 0.0003 \\
\hline Secobarbital & 367.1565 & 367.1551 & 367.1606 & 367.1576 & 0.0011 & 0.0003 \\
\hline
\end{tabular}


Supplemental Table 4. Average reverse search scores and lists of other compounds that produced reverse search scores higher than the compound of interest for the positive mode study (Study 3) on Instrument 2. The number in parentheses next to the compounds indicates how many times, out of the five replicate spectra, that compound returned a reverse search score greater than the compound of interest.

\begin{tabular}{|c|c|c|c|c|c|c|c|c|}
\hline 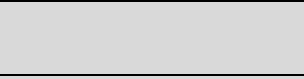 & \multicolumn{4}{|c|}{$\begin{array}{c}\text { Average Reverse Search } \\
\text { Score } \\
\end{array}$} & \multicolumn{4}{|c|}{ Other Compounds That Produced Scores Higher Than Compound } \\
\hline & $20 \mathrm{~V}$ & $30 \mathrm{~V}$ & $60 \mathrm{~V}$ & $90 \mathrm{~V}$ & $20 \mathrm{~V}$ & $30 \mathrm{~V}$ & $60 \mathrm{~V}$ & $90 \mathrm{~V}$ \\
\hline Methamphetamine & 840 & 782 & 830 & 927 & None & None & Amphetamine (5) & None \\
\hline$\alpha$-PBP & 901 & 919 & 897 & 881 & None & None & None & None \\
\hline Butylone & 899 & 848 & 941 & 966 & None & Ethylone (5) & None & None \\
\hline Ethylone & 869 & 875 & 857 & 876 & None & None & None & None \\
\hline$\alpha-P V P$ & 859 & 867 & 822 & 874 & None & None & None & None \\
\hline Phencyclidine & 881 & 852 & 878 & 890 & None & None & None & None \\
\hline Tenocyclidine & 897 & 892 & 967 & 785 & None & None & None & None \\
\hline Nandrolone decanoate & 737 & 711 & 799 & 771 & None & None & None & None \\
\hline Cocaine & 897 & 873 & 915 & 911 & None & None & None & None \\
\hline Alprazolam & 916 & 918 & 945 & 894 & None & None & None & None \\
\hline Stanozolol & 877 & 868 & 878 & 891 & None & None & None & None \\
\hline Heroin & 767 & 698 & 824 & 857 & None & None & None & None \\
\hline Furanyl Fentanyl & 862 & 845 & 876 & 879 & 3-Furanyl Fent (5) & 3-Furanyl Fent (5) & None & None \\
\hline $\begin{array}{l}\text { Furanyl Fentanyl 3- } \\
\text { Furancarboxamide }\end{array}$ & 878 & 878 & 874 & 897 & None & None & $\begin{array}{l}\text { 2-Furanyl Fentanyl } \\
\text { (2) }\end{array}$ & 2-Furanyl Fentanyl (1) \\
\hline 5-Fluoro ADB & 947 & 975 & 945 & 894 & None & None & None & None \\
\hline
\end{tabular}

Abbreviation: 3-Furanyl Fent is Furanyl Fentanyl 3-Furancarboxamide.

Supplemental Table 5. Average reverse search scores and lists of other compounds that produced reverse search scores higher than the compound of interest for the negative mode study (Study 3) on Instruments 1 and 2. The number in parentheses next to the compounds indicates how many times, out of the five replicate spectra, that compound returned a reverse search score greater than the compound of interest.

\begin{tabular}{|c|c|c|c|c|c|c|c|c|}
\hline \multicolumn{9}{|c|}{ Instrument 1} \\
\hline & \multicolumn{4}{|c|}{$\begin{array}{l}\text { Average Reverse Search } \\
\text { Score }\end{array}$} & \multicolumn{4}{|c|}{ Other Compounds That Produced Scores Higher Than Compound } \\
\hline & $20 \mathrm{~V}$ & $30 \mathrm{~V}$ & $60 \mathrm{~V}$ & $90 \mathrm{~V}$ & $20 \mathrm{~V}$ & $30 \mathrm{~V}$ & $60 \mathrm{~V}$ & $90 \mathrm{~V}$ \\
\hline AB-FUBINACA & 972 & 991 & 985 & 968 & None & None & None & None \\
\hline GHB & 970 & 971 & 933 & 776 & None & None & None & None \\
\hline Secobarbital & 938 & 956 & 939 & 906 & None & None & None & None \\
\hline \multicolumn{9}{|c|}{ Instrument 2} \\
\hline & \multicolumn{4}{|c|}{$\begin{array}{c}\text { Average Reverse Search } \\
\text { Score }\end{array}$} & \multicolumn{4}{|c|}{ Other Compounds That Produced Scores Higher Than Compound } \\
\hline & $20 \mathrm{~V}$ & $30 \mathrm{~V}$ & $60 \mathrm{~V}$ & $90 \mathrm{~V}$ & $20 \mathrm{~V}$ & $30 \mathrm{~V}$ & $60 \mathrm{~V}$ & $90 \mathrm{~V}$ \\
\hline AB-FUBINACA & 925 & 928 & 939 & 936 & None & None & None & None \\
\hline
\end{tabular}




\begin{tabular}{|l|c|c|c|c|c|c|c|c|}
\hline GHB & 854 & 941 & 970 & 819 & None & None & None & None \\
\hline Secobarbital & 945 & 962 & 953 & 953 & None & None & None & None \\
\hline
\end{tabular}

Supplemental Table 6. Average reverse search scores and lists of other compounds that produced reverse search scores higher than the compound of interest for the positive mode study (Study 3) in Instrument 2. The number in parentheses next to the compounds indicates how many times, out of the five replicate spectra, that compound returned a reverse search score greater than the compound of interest.

\begin{tabular}{|c|c|c|c|c|c|c|c|c|}
\hline & \multicolumn{4}{|c|}{$\begin{array}{l}\text { Average Reverse Search } \\
\text { Score }\end{array}$} & \multicolumn{4}{|c|}{ Other Compounds That Produced Scores Higher Than Compound } \\
\hline & $20 \mathrm{~V}$ & $30 \mathrm{~V}$ & $60 \mathrm{~V}$ & $90 \mathrm{~V}$ & $20 \mathrm{~V}$ & $30 \mathrm{~V}$ & $60 \mathrm{~V}$ & $90 \mathrm{~V}$ \\
\hline \multicolumn{9}{|c|}{ Set 1} \\
\hline Methamphetamine & 840 & 782 & 830 & 927 & None & None & Amphetamine (5) & None \\
\hline Phentermine & 876 & 895 & 855 & 831 & None & None & Benzylpiperazine (3) & None \\
\hline \multicolumn{9}{|c|}{ Set 2} \\
\hline Butylone & 899 & 848 & 941 & 966 & None & Ethylone (5) & None & None \\
\hline Dimethylone & 939 & 943 & 960 & 977 & $\begin{array}{l}\text { EDMC (1) } \\
\text { MDPA (5) }\end{array}$ & $\begin{array}{c}\text { Dimethylone (1) } \\
\text { MDPA (2) }\end{array}$ & None & None \\
\hline Ethylone & 869 & 875 & 857 & 876 & None & None & None & None \\
\hline 3,4-EDMC & 867 & 895 & 715 & 939 & $\begin{array}{c}\text { Dimethylone (4) } \\
\text { MDPA (5) }\end{array}$ & $\begin{array}{c}\text { Dimethylone (1) } \\
\text { MDPA (2) } \\
\end{array}$ & None & None \\
\hline 3,4-MDPA & 949 & 937 & 929 & 966 & None & None & None & None \\
\hline \multicolumn{9}{|c|}{ Set 3} \\
\hline Cyclopropyl Fent. & 827 & 806 & 847 & 879 & $\begin{array}{c}\text { Crotonyl (5) } \\
\text { Methacryl (5) }\end{array}$ & $\begin{array}{l}\text { Crotonyl (5) } \\
\text { Methacryl (5) }\end{array}$ & None & None \\
\hline Crotonyl Fent. & 828 & 856 & 855 & 748 & Methacryl (5) & Methacryl (5) & $\begin{array}{l}\text { Cyclopropyl (1) } \\
\text { Methacryl (5) }\end{array}$ & $\begin{array}{c}\text { Cyclopropyl (5) } \\
\text { Methacryl (5) }\end{array}$ \\
\hline Methacryl Fent. & 841 & 849 & 842 & 826 & None & $\begin{array}{c}\text { Crotonyl (1) } \\
\text { Cyclopropyl (1) }\end{array}$ & Crotonyl (1) & Cyclopropyl (4) \\
\hline \multicolumn{9}{|c|}{ Set 4} \\
\hline $\mathrm{m}-\mathrm{FBF}$ & 844 & 833 & 837 & 890 & $\begin{array}{l}\text { m-FiBF (5) } \\
\text { o-FiBF (4) } \\
\text { p-FBF (3) } \\
\text { p-FiBF (5) } \\
\end{array}$ & $\begin{array}{l}\text { m-FiBF (2) } \\
\text { o-FiBF (4) } \\
\text { p-FBF (4) } \\
\text { p-FiBF (5) }\end{array}$ & $\begin{array}{c}\text { m-FiBF (2) } \\
\text { o-FiBF (5) } \\
\text { p-FBF (5) } \\
\text { p-FiBF (5) }\end{array}$ & $\begin{array}{l}\text { o-FiBF (2) } \\
\text { p-FBF (2) } \\
\text { p-FiBF (5) }\end{array}$ \\
\hline o-FBF & 767 & 826 & 749 & 712 & $\begin{array}{c}\text { m-FiBF (2) } \\
\text { p-FBF (2) } \\
\text { p-FiBF (2) }\end{array}$ & $\begin{array}{l}\text { m-FiBF (2) } \\
\text { p-FiBF (3) }\end{array}$ & $\begin{array}{l}\text { m-FBF (4) } \\
\text { m-FiBF (4) } \\
\text { o-FiBF (4) } \\
\text { p-FBF (4) } \\
\text { p-FiBF (4) }\end{array}$ & $\begin{array}{c}\text { m-FBF (4) } \\
\text { m-FiBF (4) } \\
\text { o-FiBF (4) } \\
\text { p-FBF (4) } \\
\text { p-FiBF (4) }\end{array}$ \\
\hline $\mathrm{p}-\mathrm{FBF}$ & 852 & 830 & 875 & 799 & None & $\begin{array}{l}\text { m-FBF (1) } \\
\text { m-FiBF (1) } \\
\text { o-FiBF (5) } \\
\text { p-FiBF (5) }\end{array}$ & $\begin{array}{l}\text { o-FiBF (5) } \\
\text { p-FiBF (5) }\end{array}$ & $\begin{array}{l}\text { m-FBF (5) } \\
\text { o-FiBF (5) } \\
\text { p-FBF 95) } \\
\text { p-FiBF (5) }\end{array}$ \\
\hline $\mathrm{m}-\mathrm{FiBF}$ & 858 & 848 & 858 & 879 & $\begin{array}{c}\text { m-FBF (1) } \\
\text { m-FiBF (1) } \\
\text { o-FiBF (3) } \\
\text { p-FBF (3) } \\
\text { p-FiBF (4) }\end{array}$ & $\begin{array}{c}\text { m-FiBF (5) } \\
\text { o-FiBF (5) } \\
\text { p-FBF (4) } \\
\text { p-FiBF (5) }\end{array}$ & $\begin{array}{l}\text { o-FiBF (2) } \\
\text { p-FBF (2) } \\
\text { p-FiBF (2) }\end{array}$ & $\begin{array}{l}\text { m-FBF (1) } \\
\text { o-FiBF (5) } \\
\text { p-FBF (5) } \\
\text { p-FiBF (5) }\end{array}$ \\
\hline o-FiBF & 890 & 871 & 887 & 929 & $\begin{array}{l}\text { m-FiBF (1) } \\
\text { p-FBF (2) } \\
\text { p-FiBF (5) }\end{array}$ & $\begin{array}{c}\text { m-FiBF (2) } \\
\text { p-FBF (1) } \\
\text { p-FiBF (5) }\end{array}$ & p-FiBF (1) & $\mathrm{p}-\mathrm{FiBF}(5)$ \\
\hline p-FiBF & 909 & 889 & 890 & 967 & None & None & None & None \\
\hline
\end{tabular}




\begin{tabular}{|c|c|c|c|c|c|c|c|c|}
\hline \multicolumn{9}{|c|}{ Set 5} \\
\hline 6-APDB & 949 & 926 & 940 & 984 & $\begin{array}{c}\text { 5-APDB (1) } \\
\text { Ethcathinone (1) } \\
\text { Mephedrone (1) }\end{array}$ & None & 5-APDB (3) & None \\
\hline 5-APDB & 936 & 890 & 934 & 989 & None & None & None & None \\
\hline Buphedrone & 948 & 921 & 972 & 952 & $\begin{array}{l}\text { Ethcathinone (3) } \\
\text { Mephedrone (2) }\end{array}$ & Dimethylcath. (4) & None & None \\
\hline Dimethylcathinone & 945 & 914 & 970 & 970 & $\begin{array}{l}\text { Ethcathinone (2) } \\
\text { Mephedrone (1) }\end{array}$ & $\begin{array}{l}\text { Ethcathinone (4) } \\
\text { Mephedrone (3) }\end{array}$ & $\begin{array}{l}\text { Ethcathinone (2) } \\
\text { Mephedrone (1) }\end{array}$ & None \\
\hline Ethcathinone & 928 & 895 & 903 & 980 & $\begin{array}{l}\text { Buphedrone (4) } \\
\text { Mephedrone (3) }\end{array}$ & $\begin{array}{c}\text { Buphedrone (4) } \\
\text { Dimethylcath. (4) } \\
\text { Mephedrone (4) } \\
\text { 2-MMC (2) }\end{array}$ & None & None \\
\hline Mephedrone & 926 & 872 & 951 & 967 & $\begin{array}{c}\text { Buphedrone (3) } \\
\text { Dimethylcath. (2) } \\
\text { Ethcathinone (3) } \\
\text { 2-MMC (1) }\end{array}$ & $\begin{array}{c}\text { Buphedrone (2) } \\
\text { Dimethylcath (5) } \\
\text { Ethcathinone (1) } \\
\text { 2-MMC (1) }\end{array}$ & 2-MMC (3) & 2-MMC (3) \\
\hline 2-MMC & 903 & 845 & 944 & 953 & $\begin{array}{l}\text { Buphedrone (5) } \\
\text { Dimethylcath. (3) } \\
\text { Ethcathinone (2) } \\
\text { Mephedrone (5) }\end{array}$ & $\begin{array}{c}\text { Buphedrone (5) } \\
\text { Dimethylcath. (4) } \\
\text { Ethcathinone (2) } \\
\text { Mephedrone (4) }\end{array}$ & Mephedrone (1) & None \\
\hline MMAI & 920 & 886 & 936 & 978 & $\begin{array}{l}\text { Dimethylcath. (1) } \\
\text { Ethcathinone (2) }\end{array}$ & Dimethylcath. (4) & None & None \\
\hline
\end{tabular}


Supplemental Table 7. Average reverse search scores and lists of other compounds that produced reverse search scores higher than the compound of interest for the negative mode study (Study 3). The number in parentheses next to the compounds indicates how many times, out of the five replicate spectra, that compound returned a reverse search score greater than the compound of interest.

\begin{tabular}{|c|c|c|c|c|c|c|c|c|}
\hline \multicolumn{9}{|c|}{ Instrument 1} \\
\hline & \multicolumn{4}{|c|}{$\begin{array}{c}\text { Average Reverse Search } \\
\text { Score } \\
\end{array}$} & \multicolumn{4}{|c|}{ Other Compounds That Produced Scores Higher Than Compound } \\
\hline & $20 \mathrm{~V}$ & $30 \mathrm{~V}$ & $60 \mathrm{~V}$ & $90 \mathrm{~V}$ & $20 \mathrm{~V}$ & $30 \mathrm{~V}$ & $60 \mathrm{~V}$ & $90 \mathrm{~V}$ \\
\hline AB-FUBINACA & 972 & 991 & 985 & 968 & None & None & None & None \\
\hline AB-7-FUBAICA & 979 & 935 & 985 & 980 & AB-FUB. 2'-indazole (2) & $\begin{array}{c}\text { AB-FUBINACA (5) } \\
\text { AB-FUB. 2'-indazole (4) } \\
\text { AB-FUB. 2-fluorobenzyl (2) }\end{array}$ & None & None \\
\hline $\begin{array}{c}\text { AB-FUBINACA 2'- } \\
\text { indazole isomer }\end{array}$ & 992 & 987 & 967 & 987 & None & None & None & None \\
\hline $\begin{array}{l}\text { AB-FUBINACA } \\
\text { isomer } 1\end{array}$ & 926 & 919 & 965 & 969 & $\begin{array}{c}\text { AB-FUBINACA (5) } \\
\text { AB-FUB. 2'-indazole (5) }\end{array}$ & $\begin{array}{c}\text { AB-FUBINACA (5) } \\
\text { AB-FUB. 2'-indazole (5) }\end{array}$ & None & None \\
\hline $\begin{array}{l}\text { AB-FUBINACA 2- } \\
\text { fluorobenzyl isomer }\end{array}$ & 917 & 896 & 989 & 989 & $\begin{array}{l}\text { AB-FUBINACA (4) } \\
\text { AB-FUB. 2'-indazole (5) } \\
\text { AB-FUB. isomer 1 (2) }\end{array}$ & $\begin{array}{l}\text { AB-FUBINACA (5) } \\
\text { AB-FUB. 2'-indazole (5) } \\
\text { AB-FUB. isomer 1 (4) }\end{array}$ & None & None \\
\hline \multicolumn{9}{|c|}{ Instrument 2} \\
\hline & \multicolumn{4}{|c|}{$\begin{array}{c}\text { Average Reverse Search } \\
\text { Score }\end{array}$} & \multicolumn{4}{|c|}{ Other Compounds That Produced Scores Higher Than Compound } \\
\hline & $20 \mathrm{~V}$ & $30 \mathrm{~V}$ & $60 \mathrm{~V}$ & $90 \mathrm{~V}$ & $20 \mathrm{~V}$ & $30 \mathrm{~V}$ & $60 \mathrm{~V}$ & $90 \mathrm{~V}$ \\
\hline AB-FUBINACA & 925 & 928 & 939 & 936 & None & None & None & None \\
\hline AB-7-FUBAICA & 942 & 927 & 969 & 920 & $\begin{array}{c}\text { AB-FUB. 2'-indazole (5) } \\
\text { AB-FUBINACA (1) } \\
\text { AB-FUB. isomer } 1 \text { (1) }\end{array}$ & $\begin{array}{c}\text { AB-FUB. 2'-indazole (4) } \\
\text { AB-FUBINACA (3) } \\
\text { AB-FUB. isomer } 1 \text { (3) }\end{array}$ & None & None \\
\hline $\begin{array}{l}\text { AB-FUBINACA 2'- } \\
\text { indazole isomer }\end{array}$ & 973 & 978 & 959 & 983 & None & AB-7-FUBINACA (1) & None & None \\
\hline $\begin{array}{l}\text { AB-FUBINACA } \\
\text { isomer } 1\end{array}$ & 954 & 943 & 961 & 966 & $\begin{array}{c}\text { AB-FUB. 2'-indazole (5) } \\
\text { AB-FUBINACA (5) } \\
\text { AB-FUB. 2-fluorobenzyl (3) }\end{array}$ & $\begin{array}{c}\text { AB-FUB. 2'-indazole (5) } \\
\text { AB-FUBINACA (3) } \\
\text { AB-7-FUBINACA (5) }\end{array}$ & None & None \\
\hline $\begin{array}{l}\text { AB-FUBINACA 2- } \\
\text { fluorobenzyl isomer }\end{array}$ & 914 & 866 & 956 & 957 & $\begin{array}{c}\text { AB-FUB. 2'-indazole (5) } \\
\text { AB-FUBINACA (5) } \\
\text { AB-FUB. isomer } 1 \text { (5) } \\
\text { AB-7-FUBINACA (5) }\end{array}$ & $\begin{array}{c}\text { AB-FUB. 2'-indazole (5) } \\
\text { AB-FUBINACA (5) } \\
\text { AB-FUB. isomer } 1 \text { (5) } \\
\text { AB-7-FUBINACA (5) }\end{array}$ & None & None \\
\hline
\end{tabular}

Abbreviations: "AB-FUB. 2'-indazole" is AB-FUBINACA 2'-indazole isomer. "AB-FUB. isomer 1" is AB-FUBINACA isomer 1. "AB-FUB. 2-fluorobenzyl" is AB-FUBINACA 2-fluorobenzyl isomer. 
Supplemental Table 8. Summary results for the positive mode reproducibility studies (Study 7) for the second examiner for Instrument 1.

\begin{tabular}{|l|c|c|c|c|c|c|}
\hline & $\begin{array}{c}\text { Theoretical } \\
\boldsymbol{m} / \boldsymbol{z}\end{array}$ & $\begin{array}{c}\text { Minimum } \\
\mathbf{m} / \boldsymbol{z}\end{array}$ & $\begin{array}{c}\text { Maximum } \\
\mathbf{m} / \mathbf{z}\end{array}$ & $\begin{array}{c}\text { Average } \\
\mathbf{m} / \mathbf{z}\end{array}$ & $\begin{array}{c}\text { Standard } \\
\text { Deviation }\end{array}$ & $\begin{array}{c}\text { Coefficient of } \\
\text { Variation }(\boldsymbol{\%})\end{array}$ \\
\hline Methamphetamine & 150.1277 & 150.12589 & 150.1293 & 150.1279 & 0.0006 & 0.0004 \\
\hline$\alpha$-PBP & 218.1539 & 218.15181 & 218.155 & 218.1540 & 0.0007 & 0.0003 \\
\hline Butylone & 222.1124 & 222.10951 & 222.11467 & 222.1125 & 0.0008 & 0.0004 \\
\hline Ethylone & 222.1124 & 222.10951 & 222.11467 & 222.1125 & 0.0008 & 0.0004 \\
\hline$\alpha$-PVP & 232.1695 & 232.16827 & 232.1709 & 232.1696 & 0.0007 & 0.0003 \\
\hline Phencyclidine & 244.2059 & 244.20479 & 244.20934 & 244.2068 & 0.0009 & 0.0004 \\
\hline Tenocyclidine & 250.1624 & 250.16205 & 250.1654 & 250.1637 & 0.0008 & 0.0003 \\
\hline Nandrolone decanoate & 429.3363 & 429.3319 & 429.34076 & 429.3364 & 0.0015 & 0.0004 \\
\hline Cocaine & 304.1543 & 304.151 & 304.15845 & 304.1547 & 0.0012 & 0.0004 \\
\hline Alprazolam & 309.0901 & 309.08804 & 309.0925 & 309.0904 & 0.0010 & 0.0003 \\
\hline Stanozolol & 329.2587 & 329.25568 & 329.26178 & 329.2593 & 0.0012 & 0.0004 \\
\hline Heroin & 370.1649 & 370.16251 & 370.16959 & 370.1649 & 0.0012 & 0.0003 \\
\hline Furanyl Fentanyl & 375.2067 & 375.20428 & 375.2115 & 375.2071 & 0.0014 & 0.0004 \\
\hline $\begin{array}{l}\text { Furanyl Fentanyl 3- } \\
\text { Furancarboxamide }\end{array}$ & 375.2067 & 375.20428 & 375.2115 & 375.2071 & 0.0014 & 0.0004 \\
\hline 5-Fluoro ADB & 378.2187 & 378.2149 & 378.22354 & 378.219 & 0.0014 & 0.0004 \\
\hline
\end{tabular}

Supplemental Table 9. Summary results for the positive mode reproducibility studies (Study 7) for the second examiner for Instrument 2.

\begin{tabular}{|l|c|c|c|c|c|c|}
\hline & $\begin{array}{c}\text { Theoretical } \\
\mathbf{m} / \boldsymbol{z}\end{array}$ & $\begin{array}{c}\text { Minimum } \\
\boldsymbol{m} / \boldsymbol{z}\end{array}$ & $\begin{array}{c}\text { Maximum } \\
\boldsymbol{m} / \boldsymbol{z}\end{array}$ & $\begin{array}{c}\text { Average } \\
\boldsymbol{m} / \boldsymbol{z}\end{array}$ & $\begin{array}{c}\text { Standard } \\
\text { Deviation }\end{array}$ & $\begin{array}{c}\text { Coefficient of } \\
\text { Variation }(\boldsymbol{\%})\end{array}$ \\
\hline Methamphetamine & 150.1277 & 150.1264 & 150.1306 & 150.1287 & 0.0010 & 0.0007 \\
\hline$\alpha$-PBP & 218.1539 & 218.1511 & 218.1567 & 218.1540 & 0.0014 & 0.0006 \\
\hline Butylone & 222.1124 & 222.1097 & 222.1153 & 222.1126 & 0.0014 & 0.0006 \\
\hline Ethylone & 222.1124 & 222.1097 & 222.1153 & 222.1126 & 0.0014 & 0.0006 \\
\hline$\alpha$-PVP & 232.1695 & 232.1668 & 232.1728 & 232.1700 & 0.0015 & 0.0006 \\
\hline Phencyclidine & 244.2059 & 244.2034 & 244.2093 & 244.2065 & 0.0015 & 0.0006 \\
\hline Tenocyclidine & 250.1624 & 250.1596 & 250.1658 & 250.1629 & 0.0016 & 0.0006 \\
\hline Nandrolone decanoate & 429.3363 & 429.3326 & 429.3412 & 429.3370 & 0.0024 & 0.0006 \\
\hline Cocaine & 304.1543 & 304.1516 & 304.1582 & 304.1549 & 0.0018 & 0.0006 \\
\hline Alprazolam & 309.0901 & 309.0875 & 309.0944 & 309.0908 & 0.0019 & 0.0006 \\
\hline Stanozolol & 329.2587 & 329.256 & 329.2629 & 329.2594 & 0.0020 & 0.0006 \\
\hline Heroin & 370.1649 & 370.1617 & 370.1692 & 370.1655 & 0.0021 & 0.0006 \\
\hline Furanyl Fentanyl & 375.2067 & 375.2036 & 375.2110 & 375.2072 & 0.0021 & 0.0006 \\
\hline $\begin{array}{l}\text { Furanyl Fentanyl 3- } \\
\text { Furancarboxamide }\end{array}$ & 375.2067 & 375.2036 & 375.2110 & 375.2072 & 0.0021 & 0.0006 \\
\hline 5-Fluoro ADB & 378.2187 & 378.2154 & 378.2232 & 378.2192 & 0.0022 & 0.0006 \\
\hline
\end{tabular}


Supplemental Table 10. Summary results for the negative mode reproducibility studies (Study 7) for the second examiner for both instruments.

\begin{tabular}{|l|c|c|c|c|c|c|}
\hline & $\begin{array}{c}\text { Theoretical } \\
\mathbf{m} / \mathbf{z}\end{array}$ & $\begin{array}{c}\text { Minimum } \\
\mathbf{m} / \mathbf{z}\end{array}$ & $\begin{array}{c}\text { Maximum } \\
\mathbf{m} / \mathbf{z}\end{array}$ & $\begin{array}{c}\text { Average } \\
\mathbf{m} / \mathbf{z}\end{array}$ & $\begin{array}{c}\text { Standard } \\
\text { Deviation }\end{array}$ & $\begin{array}{c}\text { Coefficient of } \\
\text { Variation }(\boldsymbol{\%})\end{array}$ \\
\hline Instrument 1 \\
\hline AB-FUBINACA & 103.0390 & 103.0387 & 103.0406 & 103.0397 & 0.0006 & 0.0006 \\
\hline GHB & 237.1234 & 237.1227 & 237.1266 & 237.1248 & 0.0011 & 0.0005 \\
\hline Secobarbital & 367.1565 & 367.1555 & 367.1610 & 367.1584 & 0.0017 & 0.0005 \\
\hline \multicolumn{7}{|c|}{ Instrument 2 } \\
\hline AB-FUBINACA & 103.0390 & 103.0397 & 103.0412 & 103.0402 & 0.0003 & 0.0003 \\
\hline GHB & 237.1234 & 237.1235 & 237.1266 & 237.1245 & 0.0007 & 0.0003 \\
\hline Secobarbital & 367.1565 & 367.1567 & 367.1614 & 367.1582 & 0.0011 & 0.0003 \\
\hline
\end{tabular}

